\title{
THE DIVORCE PROCESS AND FAMILY (DIVORCE) MEDIATION
}

\author{
Bülent ŞEN \\ KKTC Lefke Avrupa Üniversitesi, Sağllk Bilimleri Fakültesi, Lefke / KKTC
}

ORCID ID: 0000-0003-1752-1876

Öz: Amaç: Bu araștırmada, boșanma deneyimini yașamış kadın ve erkekler ile onların çocuklarının boşanma süreci, mahkeme süreci ve boşanma sonrası yaşadıkları yaşam deneyimleri incelenmiştir. Aile (boşanma) arabuluculuğunun, boşanma ile ilgili tüm süreçlerde boşanmanın olumsuz etkilerini azaltabileceği düşüncesi ile araştırmaya katılanların aile (boşanma) arabuluculuğu fikrine nasıl baktıkları hususu sorgulanmıştır. Yöntem: Araştırmada karma model (mixed model study) kullanılmıştır. Nicel ve nitel verilerin toplanması için yapılandırılmış ve yarı yapılandırılmış görüşme formu; tek bir formda ve kadın ve erkekler için farklı olmak üzere hazırlanmıștır. Ankara Büyükșehir Belediye sınırları içinde ikamet eden boşanma deneyimini yaşamış, 53'ü kadın, 44' ü erkek olmak üzere toplam 97 katılımcı araştırmaya katılmıştır. Bulgular: Boşanma süreci ve boşanma sonrası süreç birlikte değerlendirildiğinde, hem kadın hem de erkeklerin boşanma sürecini; duygusal ve psikolojik sorunlar, kızgınlık duygusu, destek ihtiyacı, boşanmaya hazırlık durumu, boşanma gereklerine uyum boyutlarında sıkıntılı bir dönem olarak değerlendirdikleri görülmüştür. Anlaşmalı yapılan boşanmalarda da temel düșüncenin evliliği biran önce bitirmek olduğu ve hem kadınların hem de erkeklerin, boşanma sonrasında boşanmadan doğan haklarını istedikleri şekilde alamadıklarını düşündükleri görülmüştür. Sonuç: Boşanmış bireylerin "boşanma arabuluculuğu" konusuna $\% 72$ oranında olumlu bakmalarının tespiti araştırmadan çıkan en önemli sonuçtur. Ebeveyne yabancılaştırma ve ortak velayet olguları ilk defa bir araştırmada birlikte incelenmiş̧tir. Aile (boşanma) arabuluculuğu Kanun hazırlıklarına sosyal hizmet akademisyenlerinin ve konunun uzmanlarının da dahil edilmesi önerilmektedir.

Anahtar Kelimeler: Boşanma, Arabuluculuk, Aile Arabuluculuğu, Boşanma Arabuluculuğu, Ebeveyne Yabancılaşma, Ortak Velayet, Sosyal Hizmet
Abstract: Aim: In this study, the divorce process of men and women who have gone through a divorce experience and their children, the court process and the life experiences that they have experienced after getting divorced is examined. The issue whether divorce mediation will decreases the negative effects of divorce on all the processes or not and how the research participants viewed the idea of family (divorce) mediation has been questioned. Method: A mixed model study has been used at the research. The structured and semi structured interview form for the quantitative and qualitative data collection; has been prepared in one single form and different for women and men. Living in Ankara Metropolitan Municipality borders, a total of 97 participants, 53 of which were ladies and 44 of which were male participants who had a divorce experience, participated at the study. Results: When both the divorce process and the course after the divorce are evaluated together, it has been seen that the the vast majority of men and women have evaluated the entire process of divorce as a troubled time with regards to emotional and psychological feelings, with regards to the sense of anger, the need for support, preparation period for divorce and the adaptation to the requirements of divorce. It has been seen that both women and men were thinking that there are common grounds to the divorce, that the basic idea when deciding to divorce is to finish the marriage as soon as possible and that both women and men were thinking that they could not get their rights arising from the divorce. Conclusion: The most important result of the study is the identification that $72 \%$ of the divorced individuals were looking at the "family (divorce) mediation" in a positive way. The facts of Parental Alienation and joint custody have been examined in a survey together for the first time. It is proposed that the social service academics and experts of the subject should be included to work during the preparation of the law on family (divorce) mediation.

Key Words: Divorce, Mediation, Family Mediation, Divorce Mediation, Parental Alienation, Jointed Custody, Social Work

Doi: $10.17363 /$ SSTB.2019.32.4

(1) Sorumlu Yazar, Corresponding Author: Bülent ŞEN “Dr. Öğr. Üyesi - Ph.D”, KKTC Lefke Avrupa Üniversitesi Sağlık Bilimleri Fakültesi, Lefke / KKTC, bsen@eul.edu.tr, Geliş Tarihi / Date of Arrival: 22.12.2018, Kabul Tarihi / Date of Acceptance: 01.04.2019, Makalenin Türü: Type of Article: (Araşstrma Derleme ve Literatür; Research Compilation and Literature) Çıkar Çatısması, Yok - Conflict of Interest, No, Etik Kurul Raporu veya Kurum İin Bilgisi- Ethical Board Report or Institutiunal Approval, Yok/No 


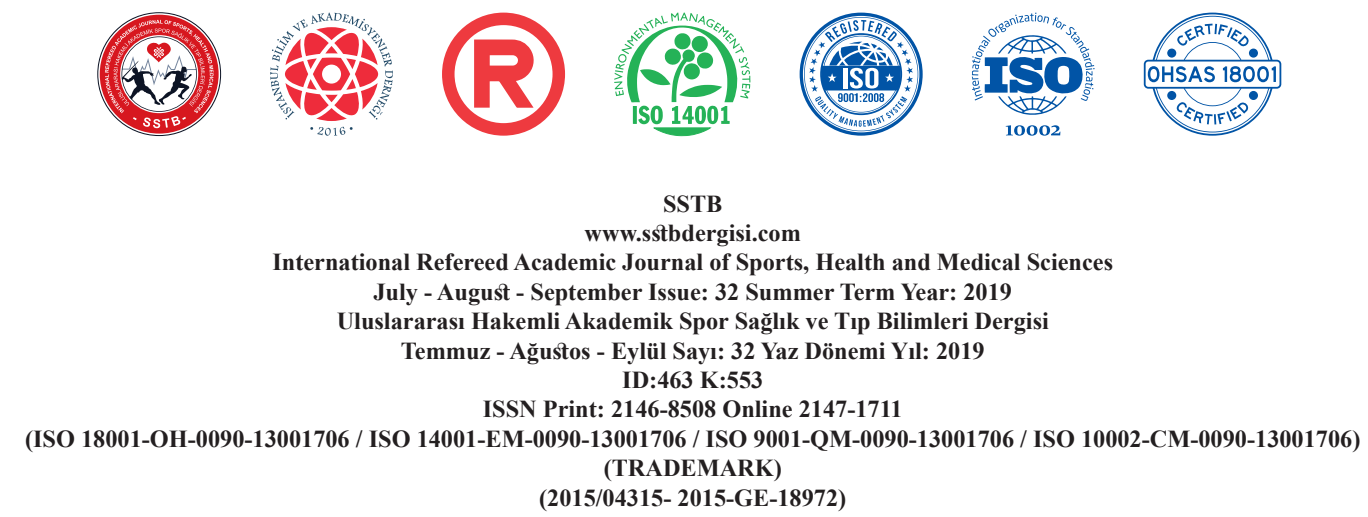

\section{GİRIŞ}

Dünyada ve ülkemizde boşanan bireylerin sayısı ve boşanma oranları giderek artmaktadır. 2017 yılında ülkemizde evlenen çiftlerin sayıs1 569.459, aynı yıl içerisinde boşanan çiftlerin sayısı ise 128.411 olarak tespit edilmiştir (TÜİK, 2018)ํ․ Boşanma süreci ve sonrasında hem ebeveynlerin hem de çocuklarının biyopsikososyal iyilik halleri için gerekli tedbirlerin doğru uygulamalarla ve bugünden alınmasına hem hukuk hem de sosyal hizmetin bilim insanları katkıda bulunmalıdır.

Boşanmış kadın ve erkeklerin, onların çocuklarının yaşadıkları sorunlar, yaşam kalitelerinin azalması, aile yapısının zayıflaması, boşanmanın toplumun tüm katmanlarını ve geleceğini etkileyen bir kuvvet çarpanı olarak diğer toplumsal sorunlara da kaynaklık etmesi sosyal hizmet mesleğinin ilgi alanına girmektedir. 2000'li yıllardan itibaren hızla artan ve toplumu son derece rahatsiz eden boşanma olgusu, aile üyelerinin boşanma süreci, mahkeme süreci ve boşanma sonrası sürecine ait yaşadıkları olumsuz deneyimlere ve bu sürecin daha olumlu geçirilmesine yönelik bilimsel bilginin yetersizliği ve gelişmiş ülkelerde yaygınlaşan alternatif uyuşmazlık çözümü uygulamalarının Türkiye'de henüz uygulanmaması bu çalışmanın temel sorunu olmuştur. Bu çalışma ile, boşanma deneyimi-

1 http://www.tuik.gov.tr/UstMenu. do?metod=temelist ni yaşayan ailelere ait, boşanmanın tüm süreçlerinde yaşam kalitelerini azaltan yaşadıkları olumsuz deneyimler ortaya çıkarılmaya çal1şılırken, aynı zamanda boşanma deneyimini yaşayacak yeni ailelerin yaşam kalitelerine katkıda bulunabilecek koruyucu ve önleyici önlemler konusunda öneriler yapılmasına çalışılmış; bu önerilerden alternatif uyuşmazlık çözümü uygulamalarından biri olan aile (boşanma) arabuluculuğunun ülkemizde de uygulanması gerekliliği araştırmacıların ve uygulamacıların dikkatine sunulmuştur.

Toplumun ve insanların yaşam kalitesini geliştirmeye yardım etmek için onların sosyal işlevselliğinin gerçekleştirilmesi gerekmektedir. Çevresi içinde birey bakış açısına sahip olan sosyal hizmetin odak noktalarından biri de bireyin yakın çevresini oluşturan aile kurumudur (Zastrow, 1995: 4-9, 64-65). "Aile; geleneksel olarak anne-baba ve çocuklar olarak tanımlanır. Aile, üyelerinin birbirlerine karşı belirli yükümlülükler üstlendikleri ve genellikle ortak ikametleri paylaştıkları birincil bir kurumdur" (Barker, 1999: 166).

"Tarih boyunca insanoğlu zamanla belirlenen sosyal normlar çerçevesinde bir aile oluşturmaya ihtiyaç duymuştur" (Yıldırım, 1993: 249).

Evlilik, birbirinden farklı ilgi, istek ve ihtiyaçlara sahip iki insanın, birlikte yaşamak, yaşantıları paylaşmak, çocuk sahibi olmak 


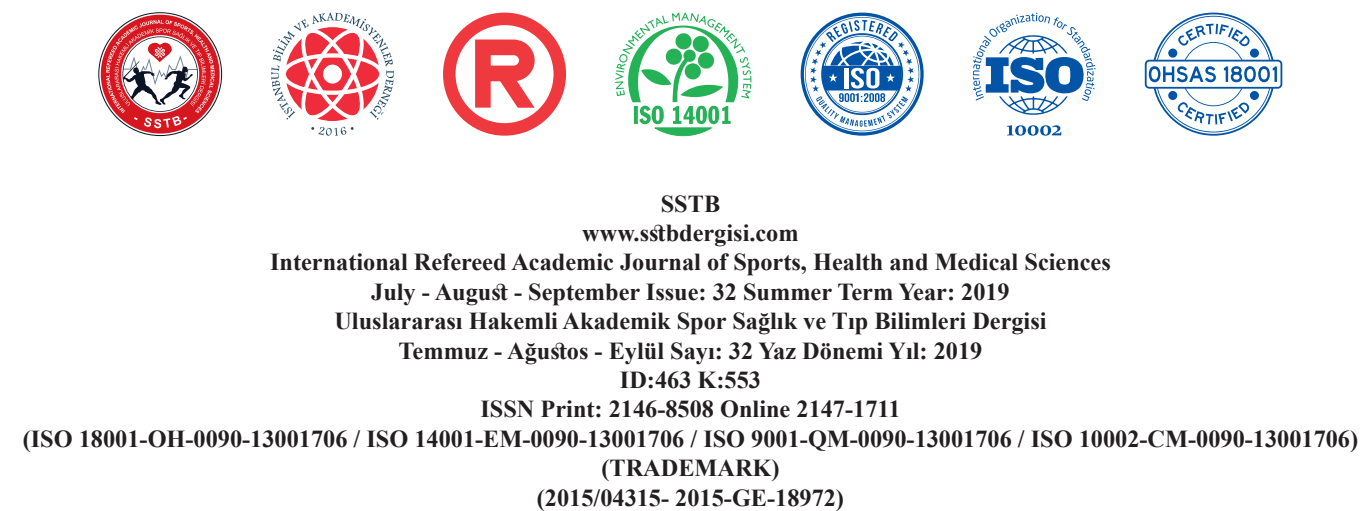

(2015/04315- 2015-GE-18972)

ve yetiştirmek gibi amaçlarla kurdukları bir ilişkiler sistemi, karşılıklı bir dayanışma ve toplumsal onaylamayla gerçekleşmiş bir sözleşme ve tüm toplumsal yasaklamalar dışında tutulan cinsel gereksinmelerin karşılıklı olarak doyuma ulaştırıldığı bir kaynaşmadır (Özuğurlu, 1990: 9). Evlilik insan hayatındaki önemli yaşantılardan sadece birisi olmasına karşın, kişinin yaşam kalitesi ile doğrudan ilişkilidir (Hünler ve Gençöz, 2003: 99). Şenel (2004: 62), eş seçiminin insan yaşant1sindaki en önemli kararlardan biri olduğunu ve bireyin geri kalan yaşamını, vereceği bu kararla birlikte birçok yönden olumlu veya olumsuz yönde etkileyebileceğini ifade etmektedir.

Boşanma, kişilikleri, sosyo-kültürel değerleri, alışkanlıkları ve tepkileri ile birbirine uyum sağlayamayan, bir arada iken herhangi biri ya da her ikisinin de sosyal, mesleki sorunlar yaşadığ malar geliştirebildiği kişilerin ayrı ayrı daha sağlıklı olabilmesi temeline dayanan bir sosyal gerçekliktir. Boşanma bazı evlilikler için kaçınılmazdır (Berksun, 2005: 6). Bu durumu Stahmann ve Hiebert (1997: 18), Premarital and Premarital Counseling isimli kitaplarında "gerçekten iki tane ruh sağlığ son derece iyi yetişkin arasında bile sağlıksız evlilik ilișkisi olabileceği bir gerçektir" ifadesi ile belirtmişlerdir. Satir (1980; Akt. Fisher, 1998:1), boşanmayı, bireyin yaşamının tüm alanlarını etkileyen metaforik bir ameliyat olarak tanımlamakta ve boşanmanın köklerinin, evlenme aşamasındaki koşullar ve umutlarda saklı olduğunu belirtmektedir.

Evliliğin bitmesine yol açan sebepler çok çeşitli olabilmesine karşın, en çok görülen sebepler şunlardır; ekonomik sorunlar, eşlerin sosyo-kültürel yapı farklılıkları, cinsel sorunlar, iletişim bozukluğu, eşlerden birinin ihaneti, aile içi şiddet, zevk ayrılıkları, eşlerin birbirlerini ihmal edişi, ailelerin aşırı müdahalesi, eşlerden biri veya her ikisinin ailelerine bağımlı ya da zayıf kişilikte olmaları, çocuk olmaması, ciddi ekonomik ve sınıfsal farklılıklar, yaş farkının fazla olması, erken yaş evlilikleri, aile baskısı ile evlendirmeler, taraflardan birinin ani kişilik ve yaşam pratiğinin değişmesi, psikiyatrik sorunlar/depresyon, panik atak, şizofreni vb., uyuşturucu, alkol ve kumar alışkanlığı (Hortaçsu, 1991: 37; Aile ve Sosyal Araştırmalar Genel Müdürlüğ̈ “Boşanma Nedenleri Araştırması”, 2009a: 138-141). Şen (2009) araştırmasında, boşanma oranlarının yükselmesine birçok faktörün katkıda bulunmasına rağmen, bunlardan evlilik için yeterince hazırlıklı olmamanın birinci sırada yer alabildiğini, bu nedenle, genç çiftlerin birbirlerini ve kendilerini gerçekçi bir yolla keşfetmelerine yardımcı olabilecek evlilik öncesi eğitimlerin alınmasının hayati bir önemi olduğunu belirtmiştir. 


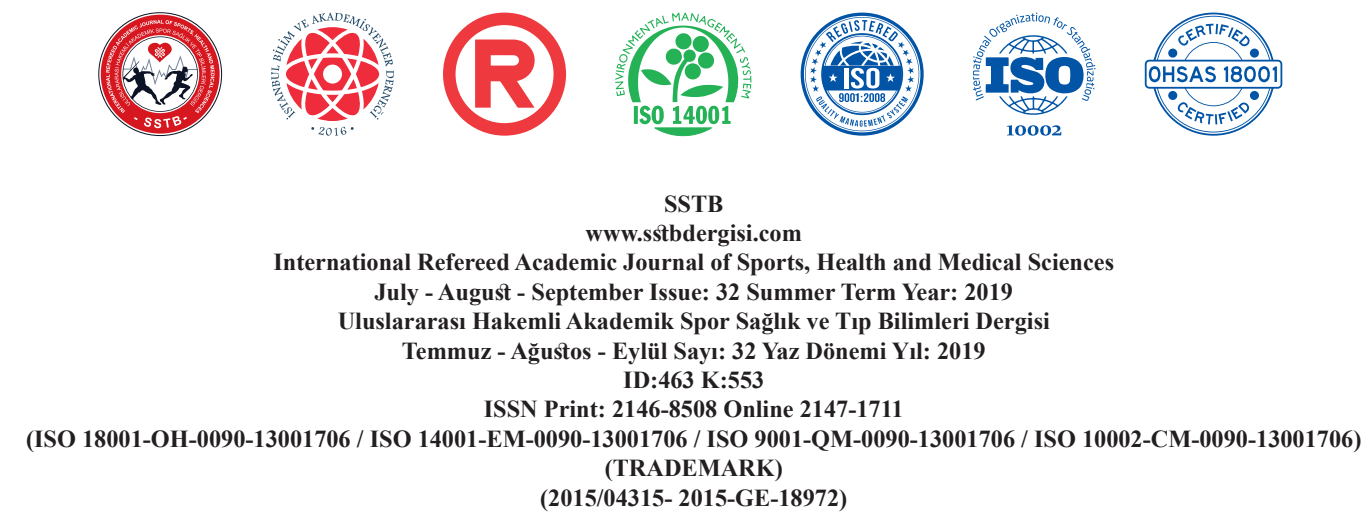

Satir (1980; Akt. Fisher, 1998: 1), boşanma sirasında ve sonrasinda üstesinden gelinmesi gereken duygusal aşamaları, ölüm sonrası yaşanan duygusal aşamalara benzetmektedir. Önceleri, meydana gelen olayları inkâr etme aşamasından geçildiğini, daha sonra olayın tümünden kendini soyutlama isteği doğduğunu, bir sonraki aşamanın öfke aşaması olduğunu, kişinin başına gelenlerden dolay1 bir başkasını suçladığını, üçüncü aşamada pazarlığın başladığını, her şeyin eşit olduğunu görme arzusuyla kara kaplı deftere bakma isteğinin doğduğunu, bu durumun genelde boşanma sırasında çocukların velayeti ve mal paylaşımı konusunda kendisini gösterdiğini, bunu depresyona girilen bir dönemin izlediğini, bu dönemde kişinin kendisinden nefret edebildiğini, kendini suçlayabildiğini ve başaramadığı kanısına kapılabildiğini, son olarak da, kişinin hem durumunu hem de kendi benliğini kabullendiği bir döneme girdiğini, bunun sonucu olarak da olabilecekler konusunda umutların yeşermeye başladığı bir dönem olarak algılanmaya başladığını belirtmektedir. Satir, bu döneme "toparlanma" adını vermekte ve toparlanma sürecine gereken süreyi tanımanın ve kişinin benliğinin felce uğramış, bastırılmış ya da bilinmeyen yönlerini canlandırmanın çok önemli olduğunu belirtmektedir. Ayrıca, her benliğin -bu durumda boşanmış kişinin- yaşamının bundan sonraki bölümüne başarısızlık yerine umutla bakmasına olanak verilmesinin altını çizmektedir.

Sosyolog ve eğitimciler boşanmanın toplumun temellerini sarsacak bir olgu olduğunu ileri sürmüşlerdir. Bunun asıl nedeni, çocukları da etkilemesi ve çocukla anne ve babalarının ilişkilerinin de boşanmadan genellikle olumsuz zarar görmeleridir. Satir (1980; Akt. Fisher, 1998: 1), pek çok kişi için boşanma süreci içinde, genelde, çaresizlik duyguları ve düş kırıklı̆̆ yaşandığını, öç alma, karşılık verme arzusuna ve umutsuzluğa kapılındığını belirtmektedir. Mathelin (2009: 64), boşanmalarda çocuğun yaşı ve etkilenmesi konusunda "Her şey ayrılmanın ana baba ve çevre tarafından nasıl yaşandığına bağlı, bir reçete sunmak ya da bir yaş sınırlaması getirmesi olanaksız." sözleriyle boşanma sürecinin iyi bir şekilde yönetilmesinin önemine işaret etmektedir. Erkan (1986: 165) yaptı̆̆ araştırma sonuçlarında; boşanma sonrası, özellikle çocuğun birlikte yaşadığı ana ya da babanın çocuğa boşanmada bir suçunun olmadığı$\mathrm{n} 1$, ona olan sevgilerinin süreceğini vurgulamasını, bunun yalnızca sözde kalmamas1, davranışlarla da gösterilmesi gerektiğini önermekte ve sevgisiz bir ortamda büyüyen çocuğun benlik tasarımının düşük olmasının yanında, çocukta bir takım bedensel ve ruhsal şikâyetlerin de başlayabileceği hususuna dikkat çekmektedir. 


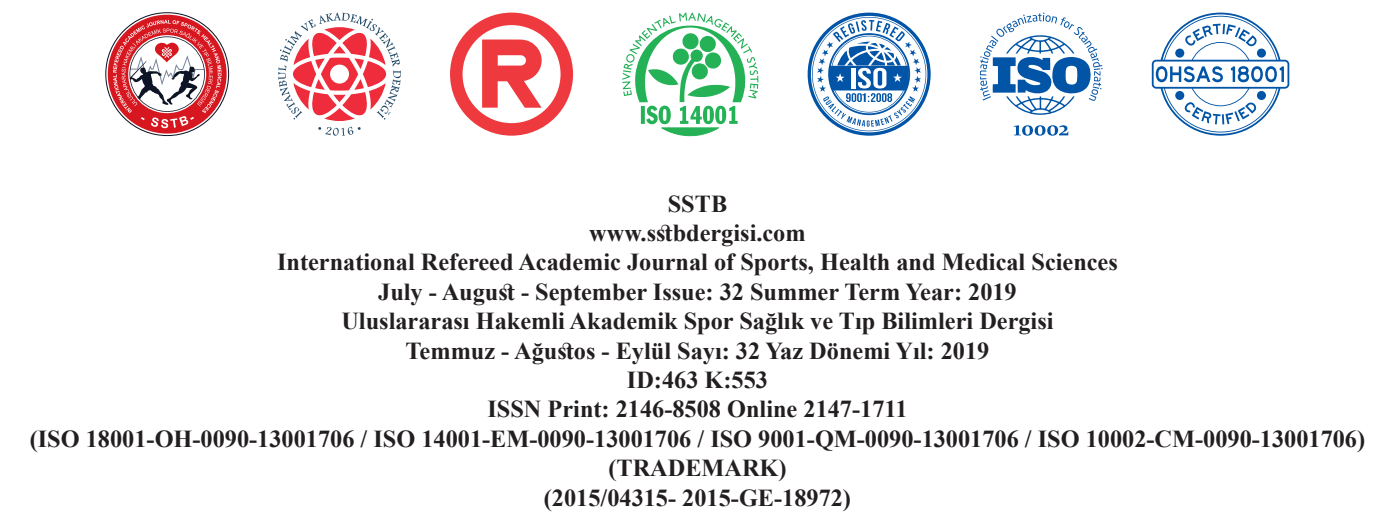

Çocuğun tüm aşamalarında oldukça olumsuz şekilde etkilendiği boşanma süreci, çoğu kez bir diğer travmatik durumla, yani ana babadan birinin evden ve çocuktan ayrılmasıyla sonuçlanmaktadır. Tam da bu noktada, çocuğun taraflarca birbirlerine karşı deyim yerindeyse bir silah olarak kullanılmaya başlaması tehlikesi doğmaktadır. Zira kimi durumlar$\mathrm{da}$, o an çocukla ilişki içinde bulunma hakkı olan ebeveynin, bu hakkı diğer eşe devretme zamanı geldiğinde zorluk çıkardığı, çocuğu teslim etmediği ve bunu yaparken karşı tarafi cezalandırma kastıyla hareket ettiği görülmektedir (Koçyıldırım, 2010: 96).

Ebeveyne yabancilaşma sendromu (EYS), genellikle çocuğun velayeti ile ilgili anlaşmazlıklarda ortaya çıkan bir bozukluk-hastalık-rahatsızlıktır. En temel göstergesi, çocuğun diğer ebeveyne karşı haksız bir iftira ve karalama kampanyası içinde olmasıdır. Programlayan (beyin yıkayan) ebeveynin aş1ladıkları ile çocuğun kendi katkılarının karışımı sonucu, hedeflenen ebeveyni kötüleme şeklinde ortaya çıkar. Temelde bunun anlamı, dile getirilen veya getirilmeyen düşünceler, hareketler, tavırlar ve davranışlar ile bir çocuğun duygusal tacize-saldırıya maruz bırakılmasıdır. Çocuğun beyni yıkanarak diğer ebeveyninin düşman olduğunu zannetmesi sağlanır. Bu, çocuğun önünde diğer ebeveyne kötü sözler sarf etmekten, diğer ebeveyn ile görüşmesinin engellenmesine, bunun için önceden başka faaliyetler hazırlanmasına kadar uzanır (Gardner, 1998: 17). Ebeveyne yabancılaşma sendromu, çocuğun annesini de babasın da sevmeye ve her ikisi tarafindan sevilmeye olan büyük ihtiyacının ebeveynlerden biri tarafindan bilinmemesi halinde yüklenmeye zorlandığı bir yüktür (Sommer, 1997; Akt. Beykont, 2012: 2). Ebeveyne yabancılaşma yaşayan çocuklar ve aileleri üzerindeki uzun dönemli etkiler oldukça ciddi olabilir ve bir dizi patolojik davranışlar geliştirebilirler;

Türkiye'de çocuğun velayeti Medeni Kanun gereği tek bir ebeveyne verilmektedir. Çocuk için en ideal olanı her iki ebeveynin de çocukla ilgili kararlara aktif katılması, çocuğun sınırlama olmaksızın istediği kadar her iki ebeveyni de görebilmesidir. Gelişmiş ülkelerde çiftler arasında giderek yaygınlaşan bir düzenleme de çocukların velayetinin müştereken (ortak) üstlenilmesidir. Bu velayet biçimi genellikle müşterek fiziksel velayet ve müşterek hukuksal velayet şeklinde uygulanmaktadır.

Son yıllarda boșanma kavramı ile ilgili üzerinde durulan yeni bir yaklaşım; boşanmanın ailenin sonu demek olmadığı, boşanma sonucunda ailenin yeni bir yapılanma sürecine girdiğidir. Yani, yasal olarak evlilik bitse bile anne ve babalık her iki ebeveyn için kalıcıdır ve devam etmektedir. Bu anlayışla, boşanma öncesi ve sonrasında koruyucu-önleyici 


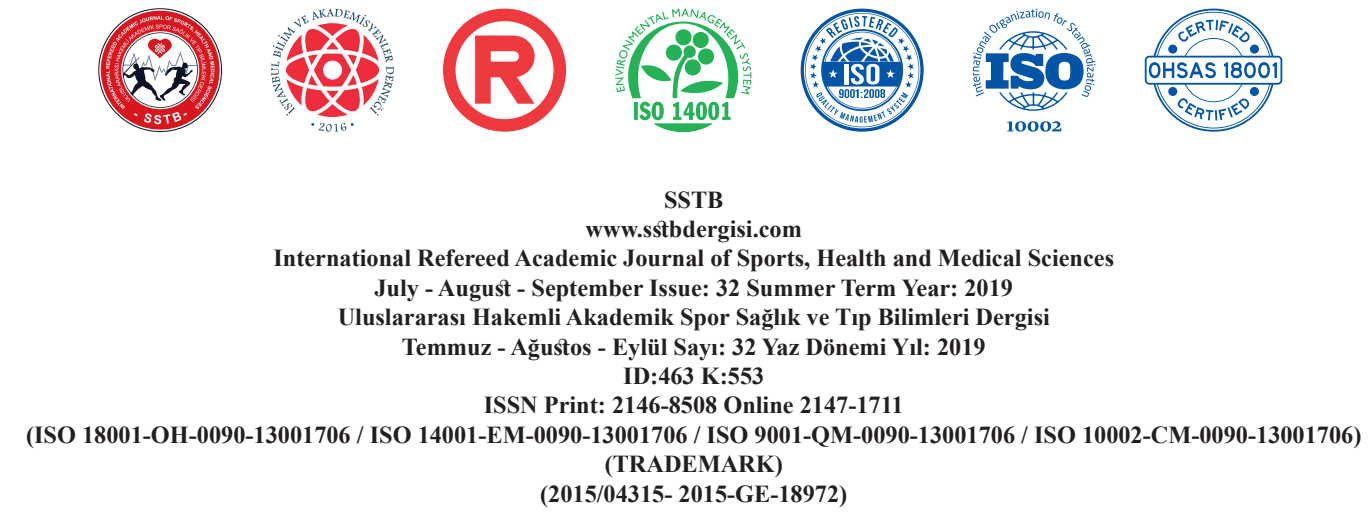

programların ortaya çıkması ve uygulanmaS1 önem kazanmıştır (Bornstein, 1988: 248254).

Ftenakis (2003) tarafindan yapılan bir değerlendirme çalışmasında Hickey (1994), Kramer (1993), Peterson (1994), Frieman (1994) ve Soderman (1995) yaptığı boşanma sonrası eğitim programlarına katılanlarda, etkili ebeveynlik anlayışının geliştiği ve eski eşleriyle daha pozitif ilişkiler yaşadıkları belirlenmiştir (Akt: Arifoğlu, 2006: 19). Boşanma sonrası uyum programların üç ana amacı vardır: Ailelerin psikolojik uyumlarını sağlamak, etkili ebeveynliği geliştirmek, aile ilişkilerini güçlendirmektir (Geasler ve Blaisure, 1998: 167-175).

C1lga (2001: 56) tarafindan yapılan tanımda da vurgulandığ gibi, sosyal hizmet disiplinler arası bir bilim dalı ve meslektir. Sosyal hizmetin bu yapısı, onun farklı disiplinler içerisinde işlevselleşmesine; aynı şekilde başka disiplinlerin de sosyal hizmetin içerisinde işlevselleşmesini beraberinde getirir. Hukuk da bu disiplinlerden bir tanesidir.

Türkiye'de Aile Mahkemeleri Kanunu ile getirilen belki en önemli değişiklik hâkimin tarafları sulha teşvik etmesidir (4787 sayılı Kanun Md.7.). Sulh yolunun ailenin tekrar bir araya gelmesine vesile olunmasinın yanında çekişmeli boşanmaların anlaşmalı boşanmaya dönüştürülerek stresli mahkeme sürecinin kısaltılması ve husumetlerin önlenmesi olarak değerlendirilebilinir. Aile ve Sosyal Araştırmalar Genel Müdürlüğü (2009b: 250)'nün “Türkiye'de Aile Mahkemeleri Uygulaması ve Uygulamanın Değerlendirilmesi" araştırması sonuçlarında; 4787 sayılı Kanun'un 7. Maddesinde öngörülen sulha davette başarı oranının çoğunlukla tek haneli rakamları geçmediği, bu duruma aile mahkemesi hâkimlerinin uzmanlardan yeterince faydalanmadığı neden olarak gösterilmektedir.

Anglo-Sakson Hukuku kaynaklı alternatif uyuşmazlık çözümü yöntemlerinin en genel tanımı; tarafsız ve objektif konumda bulunan üçüncü bir kişinin, aralarında uyuşmazlık bulunan tarafları, ortaklaşa bir çözüme ulaşmaları için bir araya getirerek iletişim kurmalarını sağlaması olarak yapılmaktadır (Tanr1ver, 2006: 151; Soygüt, 2006: 35).

Amerika Birleşik Devletleri'nde sıkça kullanılan boşanma arabuluculuğu kavramının yerine Avrupa'da aile arabuluculuğu terimi tercih edilmektedir. Aile üzerine vurgu yapılması özellikle önemlidir, çünkü bu biçimde ihtiyaçlarının göz önünde bulundurulması zorunlu olan çocuklar da birlikteliğe dahil edilebilmektedir. Ayrıca evlatlık almak, yaşlı bakımı ve miras gibi konulara ilişkin uyuşmazlıklar yalnızca ayrılık veya boşanma durumları ile sınırlı değildir. Aile arabuluculuğu temel olarak ayrılmakta olan çiftlere, özellikle çocuklu çiftlere, çocuklar ve mali konular 


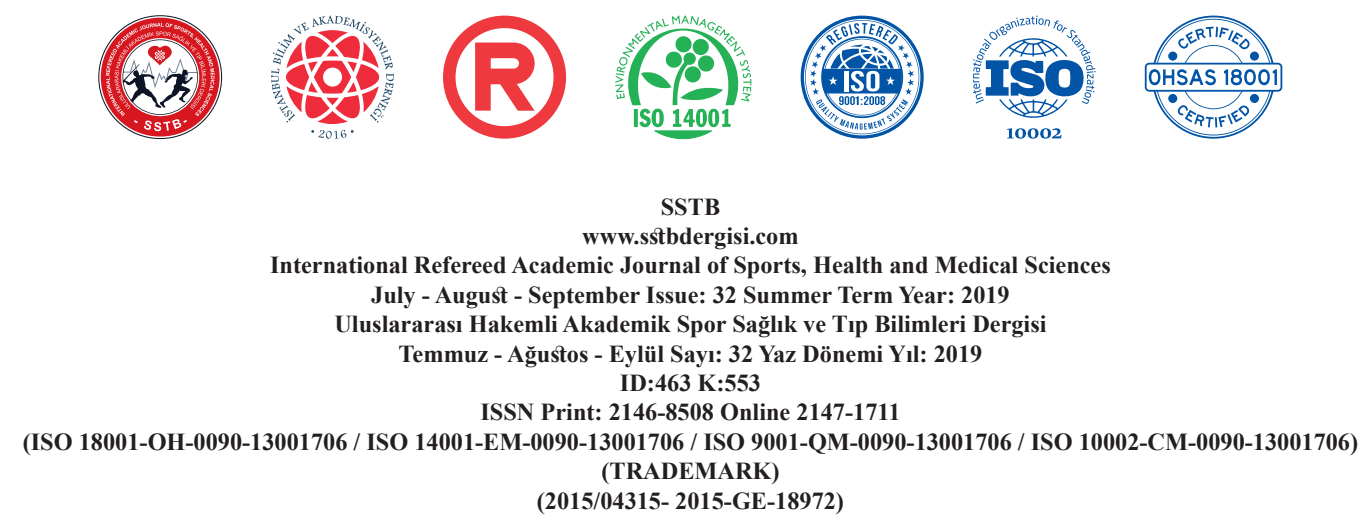

(2015/04315- 2015-GE-18972)

ya da edinilen mülklere ilişkin düzenlemeler dahil olmak üzere ayrılma veya boşanmadan kaynaklanabilecek konularda mutabakata varmalarına yardımcı olmak üzere kullanılmaktadır. Aile üyelerinin tamamı -çocuklar ve gençler, üvey anne/babalar, dedeler ve nineler -bu süreçte yer alabilmektedir. Arabuluculuk aile üyelerine kriz dönemlerinde destek olarak birbirleri ile iletişimi kesmeden uzlaşmaya dayanan düzenlemeler yapabilmelerine ya da başta çocuk-ebeveyn ilişkileri olmak üzere ilişkilerini sürdürebilmelerine ya da yeniden ilişki kurabilmelerine yardımcı olur. En önemli amaçlardan biri, ebeveynler arasında ayrılık ve boşanma gibi son derece stresli geçiş dönemlerinde iletişimi kolaylaştırmaktır. Arabulucu, çiftin birbirini dinleyerek çocuklarının ihtiyaç ve duygularını göz önünde bulunduran ortak kararlara varabilmelerine yardımcı olur (Parkinson, 2018: 9).

Koçyıldırım (2010: 98)'a göre, aile arabuluculuğunun kapsamı, aile hukukunu ilgilendiren tüm konulardır. Örneğin, mal rejimi, her türlü ebeveynlik sorumluluğu konusu, nafaka ve benzeri konular arabuluculuğun konusunu oluşturabilir. Ebeveynlik sorumluluklarının bir parçası olan velâyet ve çocukla kişisel ilişki kurulması konuları da aile arabuluculuğunun temel konuları arasındadır.

Birçok insan arabuluculuğu barıştırmaya yönelik danışmanlık veya bir tür terapi ile karıştırmaktadır. Ancak arabuluculuk ayrı bir roldür ve temel olarak danışman veya terapistlerin görevlerinden farklıdır (Parkinson, 2018: 11).

Baktır (2003: 73), arabuluculuğun taraflar arasında müzakerelerin yapılmasına yardımc1, ancak resmi olmayan bir süreç olduğunu, arabuluculukta mahkemenin re'sen arabulucuya gidilmesi kararını vermesinin olanaklı olduğunu, aile mahkemesindeki bir dosyanın taraflarının anlaşarak uyuşmazlıkların çözümünde arabulucuya gidebilecekleri gibi taraflardan biri mahkemeden arabulucu talep ettiğinde mahkemenin de arabulucuya gidilmesini emredebileceğini belirtmektedir.

C1lga (2004: 32 ve 2002), sosyal hizmetin temel hedefini; "barışçıl bir ortamda ve eşitlik içinde yaşaması için insanın ve toplumun yaşam kalitesini yükselterek, adalet, eşitlik ve özgürlük ilkelerini temel alarak; ekonomik, sosyal, kültürel ve siyasal gelişmelerle sağlanan olanakların bilimsel ve mesleki çabalarla insanın ve toplumun yararına dönüştürülmesi" olarak tanımlamaktadır. Bu tanımdan hareketle; sosyal hizmet uzmanının rollerinde de bulunan arabuluculuk rolü ile birlikte değerlendirildiğinde, sosyal hizmet ve aile (boşanma) arabuluculuğu birbiri ile örtüşmektedir. Boşanma arabuluculuğunda da eşler; barışçıl bir ortamda, eşit güçte, kendi kaderlerini etkileyecek hususlarda kendi özgür iradeleriyle tarafsız bir arabulucu önderliğinde, adil bir anlaşma yapmaya çalışmakta ve bu sürecin 


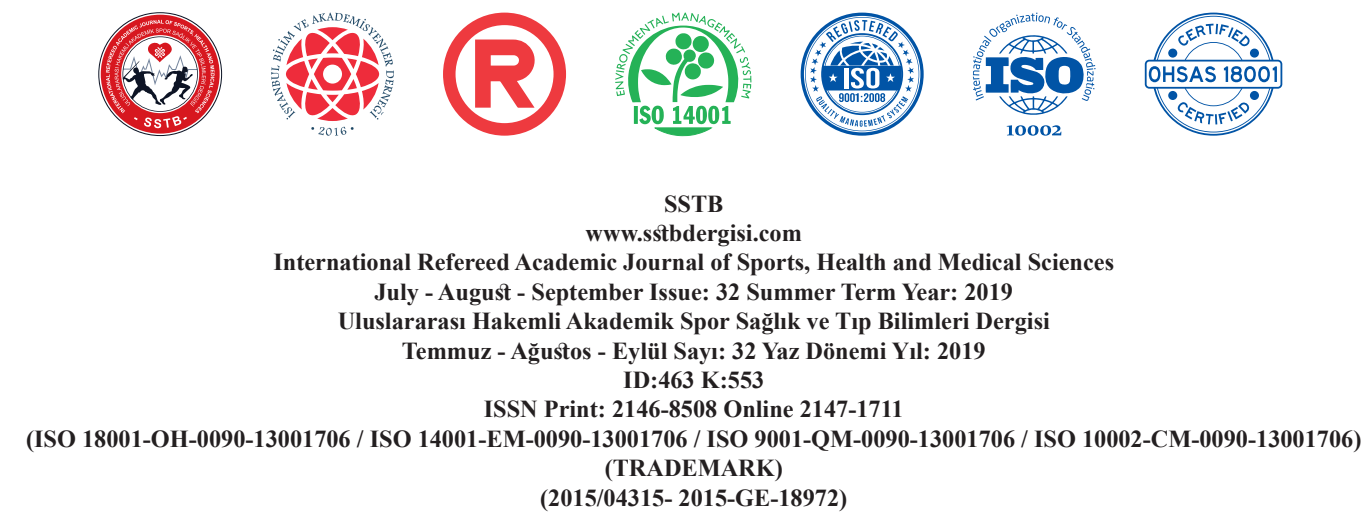

sonunda çocuklar dâhil her bir aile üyesinin boşanma sonrası yaşam kaliteleri yüksek bir hayat yaşayabilmeleri hedeflenmektedir.

Barker, (1999: 295) boşanma arabuluculuğu (divorce mediation)'nu; iki tarafin birbirine olumsuz duygularının pekiştiği süreçlerin yaşandığı aile mahkeme salonlarının dışında, boşanma sürecindeki çiftler arasındaki sorunların çözümüne yardım etmek amacıyla sosyal hizmet uzmanları, avukatlar ve diğer profesyoneller (meslek elemanları) tarafından, kullanılan bir işlem basamakları serisi olarak tanımlamaktadır. ABD'de bazı eyaletlerde bu hizmet, mahkemelerin desteğinde gerçekleştirilirken bazı eyaletlerde ise özel danışmanlık merkezleri tarafından yapılmaktadır. Boşanma arabuluculuğunun ana hedefleri; boşanma sürecindeki çiftlerin, evliliklerinde yaşadıkları sorunların nedenlerini anlamalarına, ortak mallarının eşit olarak dağllımı, çocukların velayet ve görüş günlerinin ve nafaka hususlarının düzenlenmesi, sağlıklı olmayan bir ilişkiden duygusal olarak da ayrılmak gerekliliği hususlarında farkındalıklar yaratarak çiftlerin aralarında karşılıklı kabul edilebilir uzlaşmaların yapılması olarak belirtilmektedir.

Boşanma arabuluculuğu ile ilgili yapılan araştırma sonuçlarına bakılacak olunursa; İngiltere'de yapılan bir araştırmada, boşanma arabuluculuğunun etkililiği değerlendirilmiştir. Araştırmada uygulama öncesi aile karak- teristikleri ve bireylerin psikolojik durumları belirlenmiş ve daha sonra da aile bireylerine arabuluculuk hizmeti verilmiştir. Arabuluculuk sonrası ebeveynlerin anksiyete, uykusuzluk, sosyal işlevselsizlik gibi duygusal tepkilerde azalma olduğu, aynı şekilde çocukların doyumsuzluk ve depresyon seviyelerinde de azalma olduğu tespit edilmiştir. Bu duygusal tepkilerin sonucu olarak da ebeveynler ile çocuklar arasında ve ebeveynler arasında da işbirliğinin arttığı görülmüştür (Walton, Oliver ve Griffın, 1999: 37).

Shaw (2010: 459) yaptığ bir meta-analiz çalışmasında, boşanma arabuluculuğu sistemini ve mahkeme seçeneğini kullanan çiftlerin memnuniyet durumunu incelemiş ve arabuluculuk lehine 0.36 büyüklügünde anlamlı bir fark bulmuştur. Bu çalışmasında arabuluculuk sistemini kullanan çiftlerin; süreci duygusal bağlamda daha rahat geçirdikleri, sonuç memnuniyetinin daha fazla olduğunu, mahkeme masraflarından büyük oranda kurtulduklarını, birbirlerinden daha az husumet duygusu ile ayrıldıkları ve çocuklarına etkili ebeveynlik yapabilmek için daha kolay iletişime geçebildiklerini tespit etmiştir.

Duyan (2008: 82-83), sosyal hizmet uzmanının rolleri arasında arabuluculuk rolünü; tarafların anlaşmalarına yardım etmek, farklılıkları uzlaştırmak veya her iki taraf için de tatmin edici anlaşmaya varmak için taraflar arasındaki çatışmaya müdahale etmeyi içerir 


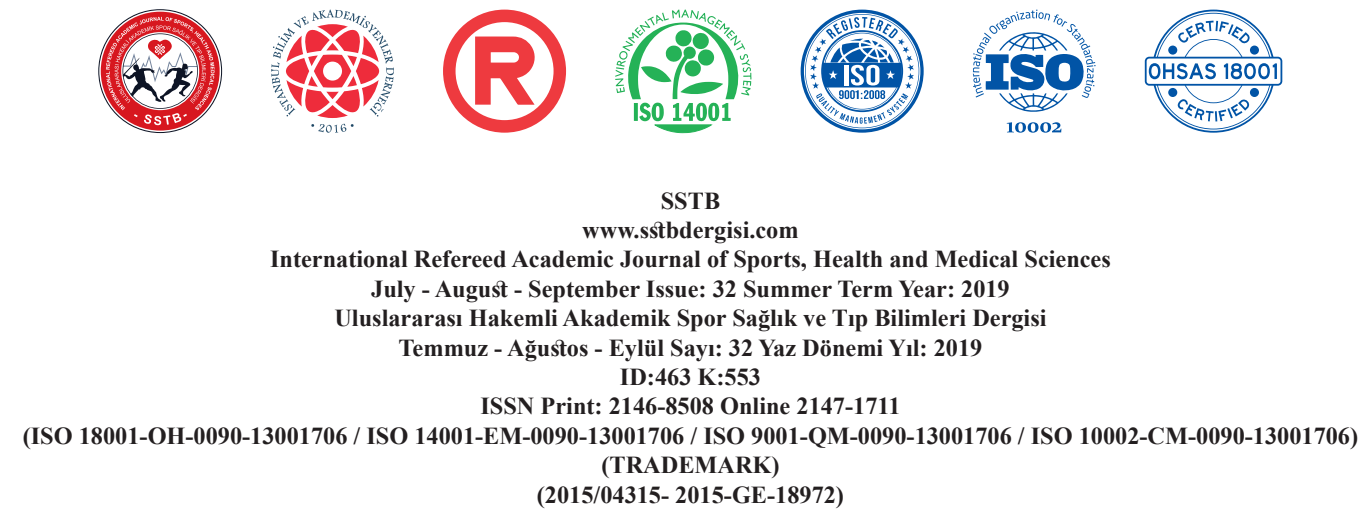

(2015/04315- 2015-GE-18972)

şeklinde açıklamıştır. Boşanma arabuluculuğu model önerisinde kullanılabilecek sosyal hizmet müdahale yaklaşımları; sosyal hizmette kriz ve krize müdahale yaklaşımı, problem çözme yaklaşımı, görev odaklı yaklaşım, sosyal hizmet müdahalelerinde güçlendirme yaklaşımı, sosyal hizmet müdahalelerinde ekolojik yaklaşım, sosyal hizmet ve aileye yönelik sosyal hizmet uygulamaları alt başlıkları altında araştırmada incelenmiştir.

$\mathrm{Bu}$ araştırmanın amacı, boşanma deneyimini yaşamış kadın ve erkekler ile onların çocuklarının boşanma süreci, mahkeme süreci ve boşanma sonrası yaşadıkları yaşam deneyimlerini tespit etmek ve araştırmaya katılanların aile (boşanma) arabuluculuğu fikrine nasıl baktıklarını belirlemektir.

\section{ÇALIŞMA GRUBU ve YÖNTEM}

Boşanma deneyimi yaşamış bireylerin araştırmaya katılma konusundaki çekinceleri, kırılgan yapıları nedeniyle yüz yüze derinlemesine görüşme bölümüne bazılarının katılmak istememesi, bir katılımcı ile birden fazla görüşme olanağının olmaması ve tüm kat1lımc1ların verdikleri nicel bilgilerin nitel bilgilerle de doğrulanması ve yorumlanmasını sağlamak üzere ve araştırmacının sınırlı olanakları nedeniyle nitel ve nicel veriler birlikte toplanmıştır. Bu nedenle Creswell (2009: 205)'in bahsettiği tasarım tiplerinden iki yaklaşımın değişik yönlerinin araştırmanın tüm aşamalarında birbirleriyle harmanlandı ğ karma-yöntem tasarımı kullanılmıştır. Karma model çalışmaları, araştırma sürecinin farklı aşamalarında nitel ve nicel yaklaşımları birleştirmektedir (Tashakkori ve Teddlie, 1998: 13-18).

Araştırmanın özneleri, boşanma deneyimini yaşamış ve boşanmaları hukuki olarak da aile mahkemeleri tarafından onaylanmış kadın ve erkeklerdir. Boşanmaları kesinleşmiş bireylerle görüşmenin temel nedeni, bireylerin boşanma sürecinin çeşitli aşamalarını yaşamış olmaları ve bu deneyimleri çok boyutlu biçimde araştırmacı ile paylaşabilecek bir aşamaya gelmiş olmaları olarak değerlendirilmiştir. Araştırmanın öznelerine ulaşmada niteliksel araştırma yönteminin amaçlı örnekleme tekniğine başvurulmuştur. Boşanma deneyimini yaşamış kadın ve erkeklerin tespiti amacıyla boşanma avukatları, aile danışma merkezleri, Boşanmış Babalar Platformu, Boşanmış Anneler Derneği, aile eğitimi veren vakıf ve dernekler ile yakın çevreden destek istenmiştir. Sonuç olarak Ankara Büyükşsehir Belediye sınırları içerisinde ikamet eden 53'ü kadın, 44' ü erkek olmak üzere toplam 97 gönüllü katılımcı araştırmaya katılmıştır.

Araştırmada iki aşamada veriler toplanmıştır. Veri toplama sürecinde birinci aşamada veri toplama araçları aynı zamanda uygulanmıştır. İlk aşamada nicel ve nitel bilgilerin topland1ğ1 görüşme formu 97 katılımcıya verilmiş ve 


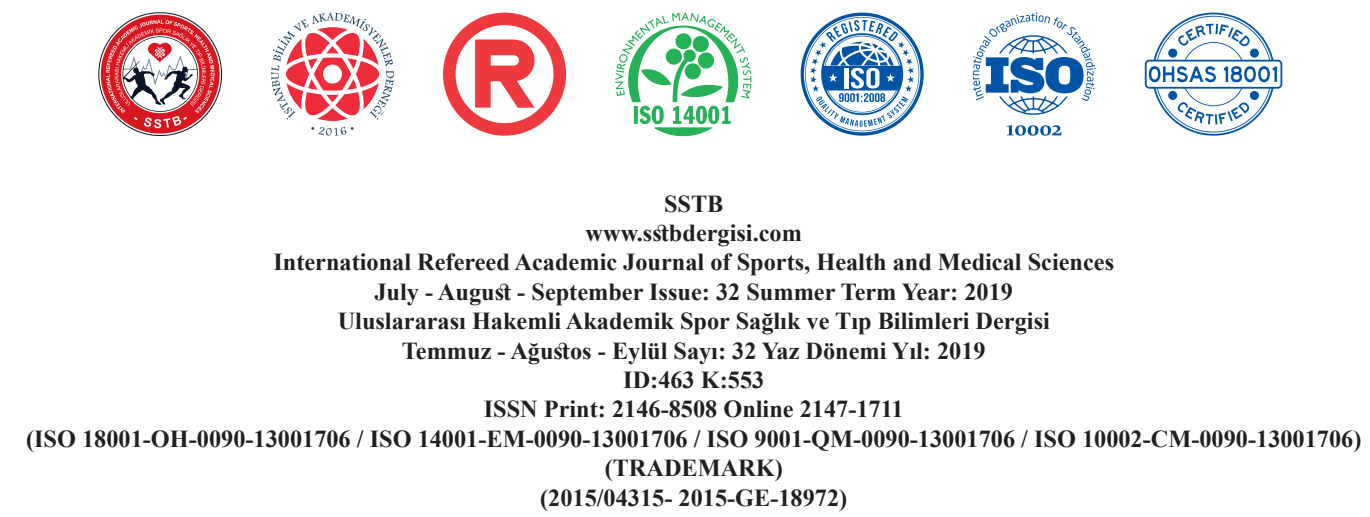

bu formların doldurulmasını müteakip ikinci aşamada derinlemesine yüz yüze görüşme yapmayı kabul eden 56 katılımc1 ile beden dili, duygu durumu, anlık ifadelerin izlenmesiyle nitel bilgilerin zenginleştirilmesine çaba harcanmıştır. Görüşmelerde ses kayıt cihazı kullanılması sorulmuş ve ancak 8 katılımcı buna izin vermiştir.

Görüş̧me formu: yapılandırılmış (nicel bilgiler için) ve yarı yapılandırılmış görüşme formu (nitel bilgiler için) olarak tek bir formda ve kadın ve erkekler için farklı olmak üzere hazırlanmıştır. Yarı yapılandırılmış derinlemesine görüşme yönergesinde öznelerin boşanma süreci, mahkeme süreci ve boşanma sonrası yaşam deneyimlerini çok boyutlu olarak kavramayı hedefleyen, yönlendirici olmayan, yansız, genel nitelikte ve ağırlıklı olarak süreci ve "anlamı" keşfetmeye yönelik açık uçlu sorulardan oluşmuştur. Katıııcıların büyük çoğunluğu görüş̧me formunun çok detaylı ve neredeyse evlilik ve boşanma sürecinde yaşanan her bir ayrıntıyı kapsad1ğını, soruları gördükçe her bir detayı yeniden hatırladıklarını bazen rahatsızlık duygusu hissettiklerini bazen bu sıkıntıları atlatabilmiş oldukların fark ederek rahatladıklarını, duygularını bir kâğıda yazarak sanki bir anlamda yüreğinin bir köşesinde kalmış acıların hafiflediğini belirtmişlerdir.

Derinlemesine yüz yüze yapıllan görüşme s1rasında sorular, konuşma tarzında, yönlendi- rici olmayan, yansız olarak sorulmuş, teşvik edici ve geri bildirimli bir şekilde görüşme sürdürülmüştür. Görüşme formunun esnek bir özelliğe sahip olması sayesinde görüşme surasinda anlık ve alternatif sorularla konunun daha iyi anlaşılmasına çalışılmıştır. Derinlemesine yüz yüze görüş̧meler 20 dakika ile 2 saat arasında ve ortalama 45 dakika sürmüştür. Bu görüşmeler özel bir aile danışmanlık merkezinin görüşme odasında (ASPB OLGU Özel Aile Danışma Merkezi Meşrutiyet C. 31/11), katılımcıların çalıştıkları iş yerlerinde (boş oda veya kafeteryaları) gerçekleştirilmiştir. Görüşmenin başlangıcında, çalışmanın amac1, kapsamı, etik hassasiyetleri ve gelecekte olası yararları anlatılmıştır. Birçok karşı1lklı derinlemesine yapılan görüşmede; katılımcıların boşanma süreci, mahkeme süreci ve boşanma sonrası süreçte yaşadıklarını yeniden yaşıyor gibi huzursuz bir beden dili ile anlatmaları ve özellikle bu süreçte ihmal edilen çocukları ile ilgili duygu ve ifadeleri ve pişmanlıkları araştırmacının dikkatini çekmiştir.

Araştırmada kullanılan görüşme formundan elde edilen nicel bilgiler SPSS $11.5 \mathrm{pa}-$ ket programı yardımıyla çözümlenmiş̧ir. Bu araştırmada boşanma deneyimi yaşayan kadın ve erkeklerle yapılan görüşmeler sonucunda elde edilen nitel veriler betimsel analiz yöntemi ile yorumlanmıştır. Araştırmaya katılan bireylerin gerçek isimleri etik hassasiyetler 


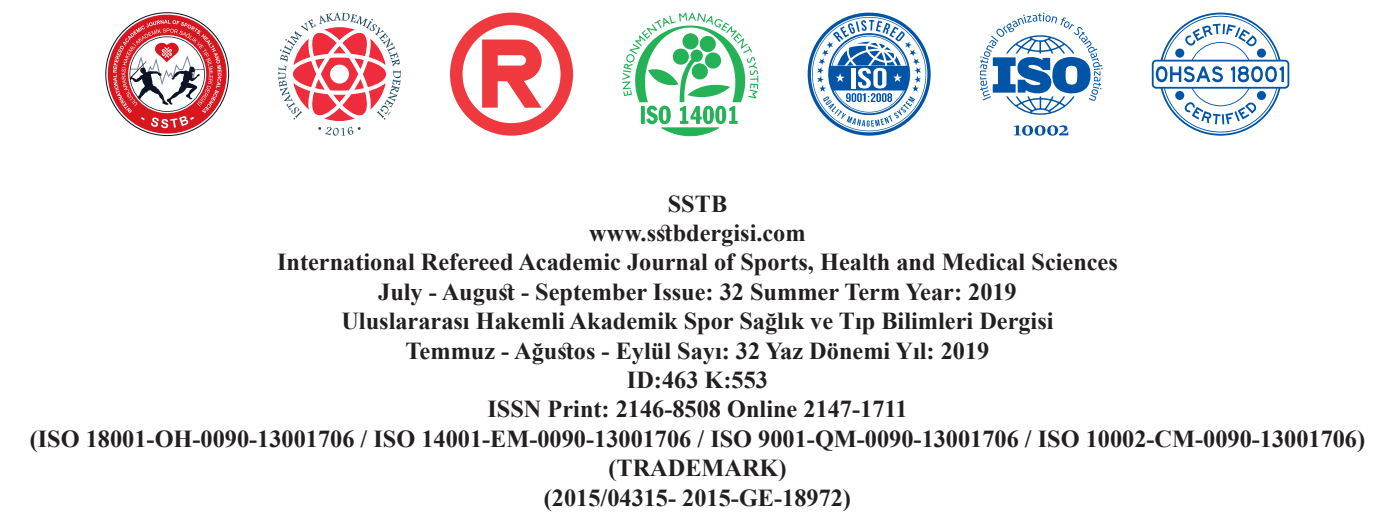

nedeniyle saklı tutulmuş, bunun yerine öznelerin tümüne araştırmacılar tarafından özgün rumuzlar (A harfi anlaşmalı boşanmayı ifade edecek şekilde) verilmiştir. Uygulama süreci Temmuz 2012 ile Şubat 2013 tarihleri arasında gerçekleştirilmiştir. Boşanma deneyimi yaşayan 97 kişi ile yapılan görüşmeler sonlandırıldıktan hemen sonra gerek yazılı olarak görüşme formunda verilen gerekse karş1lıklı görüşmeler ile ve ses kaydı ile yapılan görüşmeler çözümlenmiş ve nitel veriler elde edilmiştir. Bu çalışmada araştırma verileri dört temada (18 kategori) değerlendirilmiştir. Nitel verilerin analizi sürecinden elde edilen bulguların sayısal dökümü ve genelleştirilmesi kaygısı yerine boşanmış bireyler tarafindan inşa edilmiş öznel gerçeklik ve yaşam deneyimleri ilgili bağlam içinde kavranarak resmedilmeye çalışılmıştır.

$\mathrm{Bu}$ araştırmada boşanma deneyimi yaşayan kadın ve erkeklerle yapılan görüşmeler sonucunda elde edilen nitel veriler betimsel analiz yöntemi ile yorumlanmıştır. Betimsel analiz, çeşitli veri toplama teknikleri ile elde edilmiş verilerin daha önceden belirlenmiş temalara göre özetlenmesi ve yorumlanmasını içeren bir nitel veri analiz türüdür. $\mathrm{Bu}$ analiz türünde araştırmacı görüştüğü ya da gözlemiş olduğu bireylerin görüşlerini çarpıcı bir biçimde yansitabilmek amaciyla doğrudan alıntılara sık sık yer verebilmektedir. Bu analiz türünde temel amaç, elde edilmiş olan bulguların okuyucuya özetlenmiş ve yorumlanmış bir biçimde sunulmasıdır (Yıldırım ve Şimşek, 2005: 158).

Betimsel analiz, dört aşamada gerçekleşmektedir. Birinci aşamada araştırmacı araştırma sorularından, araştırmanın kavramsal çerçevesinden ya da görüşme ve gözlemlerde yer alan boyutlardan hareket ederek veri analizi için bir çerçeve oluşturur. Böylece verilerin hangi temalar altında düzenleneceği ve sunulacağ $\breve{b}$ belirlenmiş olur. İkinci aşamada araştırmacı daha önce oluşturmuş olduğu çerçeveye dayalı olarak verileri okur ve düzenler. $\mathrm{Bu}$ süreçte verilerin anlamlı ve mantıklı bir biçimde bir araya getirilmesi önem taşımaktadır. Üçüncü aşamada araştırmacı düzenlemiş olduğu verileri tanımlar. Bunun için gerekli yerlerde, doğrudan alıntılara da başvurmak zorunda kalabilir. Dördüncü aşamada araştırmacı, tanımlamış olduğu bulguları açıklar, iliş̧kilendirir ve anlamlandırır. Araştırmacı bu aşamada ayrıca yapmış olduğu yorumları daha da güçlendirmek için bulgular arasındaki neden sonuç ilişkilerini açıklar ve gereksinim duyulması durumunda farklı olgular arasında karşılaştırma yapar (Yıldırım ve Şimşek, 2005: 159).

Boşanma deneyimi yaşayan 97 kişi ile yapılan çalışma sonlandırıldıktan hemen sonra gerek yazilı olarak görüşme formunda verilen gerekse karşıllklı görüşmeleri kabul eden 56 katılımcı ile (bunlardan ses kaydına izin 


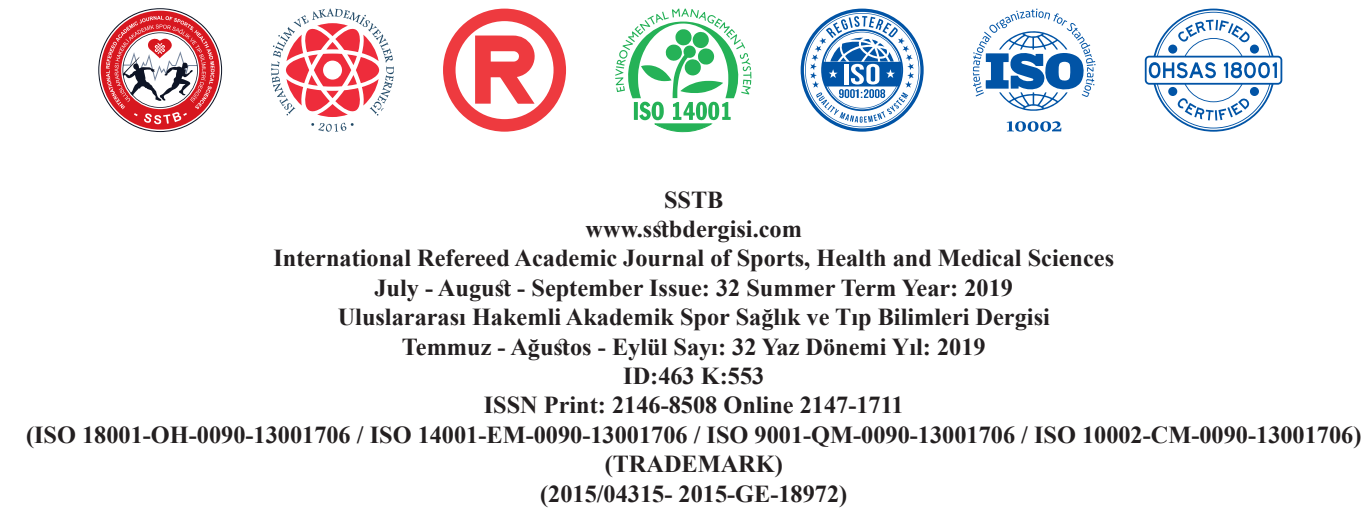

veren sekiz katılımc1) yapılan görüş̧meler çözümlenmiş ve nitel veriler elde edilmiştir. $\mathrm{Bu}$ çalışmada araştırma verileri dört temada (18 kategori ve 84 alt kategori) değerlendirilmiştir. EK-Çizelge 1'de araştırma verileri doğrultusunda oluşturulan temalar, kategoriler ve alt kategorileri verilmiştir. Çizelgeden de anlaşılacağı üzere araştırma amaçları ile paralel dört temanın çok farklı boyutlarda kategorileri ve alt kategorileri oluşturulmuştur. "Bölümleme, kodlama ve kategorileştirmeye dayalı veri çözümleme yaklaşımları, verilerdeki düzenlilikleri bulma ve kavramsallaştırma konusunda dikkate değer girişimlerdir. Fakat, bunlar hiçbir şekilde verileri ve verileri keşfetme olanaklarını tüketisiye değerlendirmez." (Punch, 2005: 210). "Nitel verilerin çözümlenmesinde bilgisayarların kullanılmas1, bütün çözümleme yöntemleri için uygun olmasa bile, bugün, niteliksel araştırmalara yardımcı olabilecek bir dizi program vardır. Belirli bir niteliksel araştırma için bilgisayar kullanımının uygun olup olmadığına araşıımacının, araştırmada hangi nitel veri çözümleme tekniğini kullanacağını belirledikten sonra karar verilir" (Punch, 2005: 221). Nitel verilerin analizi sürecinden elde edilen bulguların sayısal dökümü ve genelleştirilmesi kaygısı yerine boşanmış bireyler tarafından inşa edilmiş öznel gerçeklik ve yaşam deneyimleri ilgili bağlam içinde kavranarak resmedilmeye çalışı1mıştır.

\section{BULGULAR}

Araştırmanın amaçlarına bağlı olarak, araştırmanın verileri, nicel ve nitel olmak üzere iki yöntem kullanılarak elde edilmiştir. Nicel veriler nicel sorular ile beşli likert ölçeğine göre, sosyo-demografik özellikler, boşanma süreci, mahkeme süreci ve boşanma sonrası boşanma deneyimini yaşayan bireylerin ve çocuklarının durumlarını; nitel veriler ise bu süreçlerde yaşadıkları yaşam deneyimlerini ve boşanma arabuluculuğu sistemi hakkındaki görüşlerini açık uçlu sorulara verdikleri ifadelere ilişkin bulguları kapsamaktadır.

Araştırma sonucunda elde edilen bulgular ve yorumları altı temel başlık altında ele alınmıştır. Araştırmaya katılan boşanma deneyimini yaşamış katılımcıların sosyo - demografik ve sosyo - ekonomik özellikleri, aile içi şiddet olgusuna ilişkin bulgular, boşanma sürecinde elde edilen bulgular, boşanma sonrası süreçte elde edilen bulgular, mahkeme sürecinde elde edilen bulgular ve son bölümde katılımcıların bu süreçler ve boşanma arabuluculuğu hakkındaki düşüncelerine yönelik bulgular yer almaktadır.

Toplam 97 katılımcının araştırmaya katıldığ andaki yaş ortalamasının 40.11 olduğu, evlilik yaptığı yaş ortalamasının kadınlarda 22.2 ve erkeklerde 27 olduğu, evli kalınan ortalama sürenin 8.95 yıl olduğu, 97 katılımcıdan 41 'inin (\% 42,3) evliliklerinin ilk beş y1lında 


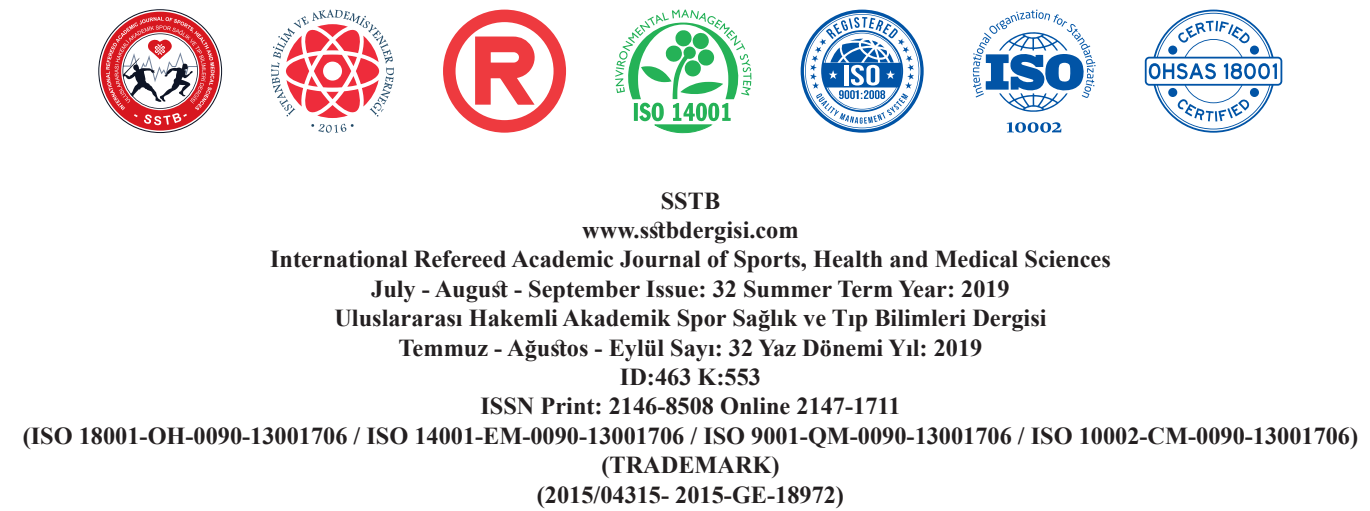

(2015/04315- 2015-GE-18972)

ayrıldıkları, boşanma yaş ortalamasının 34; en düşük boşanma yaşının 19, en yüksek boşanma yaşının 49 olduğu, evlilik öncesi ortalama flört süresinin 1 yıl 3 ay; evlilik öncesi en düşük flört süresinin 2 ay, evlilik öncesi en yüksek flört süresinin 8 yıl olduğu belirlenmiştir. Toplam 97 katılımcidan 7'sinin $(5 \mathrm{~K} / 2 \mathrm{E})$ İlkokul, 6'sinın (3K/2E) ortaokul, 27'sinin lise (15K/12E), 6'sının ön lisans (4K/2E), 45'inin (23K/22E) yüksekokul, 5'inin (3K/2E) yüksek lisans, 1 erkeğin de doktora eğitimi aldığ saptanmıştır. 97 katılımcıdan 93 katılımcının çalıştı̆̆ı, 4 kattılımoının çalışmadığ (1 erkek, 3 kadın), boşanma öncesi 14 kadının çalışmadığı, bunlardan 11'inin boşanma sonrası işe başladığı, iş bulanlardan 10'unun kolay iş bulamadığ lama gelirinin 2.150 TL.; en düşük gelir 650 TL, en yüksek gelir 5000 TL. olarak belirlenmiştir. 97 katılımcının araştırmaya katıldı̆̆ andaki sahip olduğu çocuk sayısının 109 (kız çocuk: 38, erkek çocuk: 71; boşanma anında 0-6 yaş aralığında 61 çocuk (\% 56), 7-18 yaş aralı̆̆ında 48 çocuk (\% 44), en az çocuk say1s1 (çocuk yok), en yüksek çocuk sayısı 3 (çocuk yok: 20 kişi, bir çocuk: 51 kişi, iki çocuk: 20 kişi, üç çocuk: 6 kişi) olarak belirenmiştir. 97 katılımcıdan 69 katılımoının eski eşleriyle aynı şehirde yaşadığı, 28 katılımcının farklı şehirlerde yaşadığı, toplam 97 katılımcıdan 56'sının anlaşmalı boşanma ( 15 'i çekişmeli boşanmadan sonra anlaşmalı boşanma), 41'inin ise çekişmeli boşanma ile ayrıldıkları tespit edilmiştir. Boşanmaların mahkeme süreci ortalama bir y1l olarak saptanmıştır (bu araştırmada anlaşmalı boşanmaların mahkeme sürelerini azalttığı göz önüne alınarak değerlendirilmelidir).

Araştırmada; araştırmaya katılan 53 kadının evlilik boyunca 32 'sine $(\%$ 60,4), boşanma sürecinde 19 'una (\% 35,9), boşanma sonrasında 8'ine (\% 15,1) karşı değişen sıklıkta fiziksel şiddet uygulandığı belirlenmiştir.

Araştırmada; araştırmaya katılan 53 kadının evlilik boyunca 46 'sına $(\% 86,8)$, boşanma sürecinde 43 'üne $(\% 81,2)$, boşanma sonrasında 31 'ine $(\% 58,5)$ karşı değişen sıklıkta duygusal şiddet uygulandığı belirlenmiştir.

Araştırmada; araştırmaya katılan 53 kadının evlilik boyunca 37'sine $(69,8)$, boşanma sürecinde 34'üne $(\%$ 64,2) karşı değişen sıklıkta ekonomik şiddet uygulandığı belirlenmiştir.

Araştırmada; araştırmaya katılan 53 kadının evlilik boyunca 21 'ine (\% 39,6), boşanma sürecinde 12 'sine $(\% 22,6)$, boşanma sonrasında 6'sına $(\% 11,3)$ karşı değişen sıklıkta cinsel şiddet uygulandığı belirlenmiştir.

Aile içi şiddet boyutunda evlilikleri boyunca erkeklerin de değişik sıklıkta \% 29,5 fiziksel şiddete, $\% 68,2$ duygusal şiddete ve $\% 38,6$ ekonomik şiddete uğradıkları belirlenmiştir.

Araştırma sonucunda; hem boşanma süreci hem de boşanma sonrası süreç birlikte değer- 
International Refereed Academic Journal of Sports, Health and Medical Sciences July - August - September Issue: 32 Summer Term Year: 2019

Uluslararası Hakemli Akademik Spor Sağlık ve Tıp Bilimleri Dergisi Temmuz - Ağustos - Eylül Sayı: 32 Yaz Dönemi Yıl: 2019 ID:463 K:553

ISSN Print: 2146-8508 Online 2147-1711

(ISO 18001-OH-0090-13001706 / ISO 14001-EM-0090-13001706 / ISO 9001-QM-0090-13001706 / ISO 10002-CM-0090-13001706) (TRADEMARK)

lendirildiğinde, kadın ve erkeklerin boşanma sürecinin tamamını duygusal ve psikolojik, kızgınlık duygusu, sağlıklı savunma mekanizmalarının kullanılması, destek ihtiyacı anlamında sıkıntılı bir dönem olarak değerlendirdikleri ve kafalarının karışık olduğu, bazı bireylerin duygusal olarak boşanmaya hazır olmadan boşanmaya zorlandıkları sonucuna ulaşılmıştır. Ayrıca boşanmaya eski eşin neden olduğunu düşünen ve onu suçlayanların oranının \% 91, 7 olduğu da belirlenmiştir.

Anlaşmalı olarak boşanan 56 kadın ve erkeğin yarısına yakınının evliliği biran önce bitirme düşüncesi ile ve anlaşmalı boşanmanın getirilerini (olumlu boyutunu) düşünmeden (bazen bilgisizlik bazen düşünemeden, kısa zamanda ve anlaşmalı boşanmaya zorlanarak) ayrıldı̆̆ tespit edilmiştir.

97 katılımcidan 56'sinın (tam anlamiyla olmasa bile) anlaşmalı boşanma ile boşanmış olmasına rağmen nitel ifadelerle birlikte değerlendirildiğinde mahkeme sürecinden ve verilen kararlardan olumsuz yönde etkilendikleri, çekişmeli boşanma ile boşananlar kadar olmasa da mahkeme süreci sonunda birbirlerine eskisinden daha fazla kızgın ve kırgın oldukları ve birbirlerine ve ailelerine husumet duyguları taşıdıkları sonucuna ulaşılmıştır.

Kadın ve erkeklerin boşanma sonrasını boşanmaya uyum anlamında, sıkıntılı bir dö- nem olarak değerlendirdikleri tespit edilmiştir. Kadın ve erkeklerin boşanma sonrasında boşanmadan doğan haklarını istedikleri şekilde alamadıklarını düşündükleri sonucuna ulaşı1mıştır.

Araştırmanın nitel bulgularının analizinde “ebeveyne yabancılaşma sendromu” nu çağrıştıracak kod ve kavramlar araştırmacıların dikkatini çekmiş ve "ebeveyne yabancılaşma sendromu" bir tema olarak seçilmiştir. $\mathrm{Bu}$ tema altındaki bulgular; boşanma, mahkeme ve boşanma sonrası süreçte ebeveynlerin bilinçli ve bilinçsiz olarak çocuğa uyguladığ 1 bir duygusal ve psikolojik taciz çeşidi olan ebeveyne yabancılaşma örneklerinden ilgi çekici olan bazıları aşağıda sunulmuştur (A harfi anlaşmalı boşanma ile boşanmış bireyleri tanımlamaktadır).

Araştırmaya katılan velayet kendisine verilen annelere ortak çocuklarını velayet kendisine verilmeyen babaya karşı koz olarak kullanıp kullanmadıkları sorulmuş ve;

Kadın 3 (A): Kizgınlık esnasında uzak tutmaya çalıştım. Sonra bu yaptığımın yanlış olduğuna karar verdim.

Kadın 11: Evet öfkemden dolayı çocuğumla cezalandirdim.

Kadın 31: Babasına karşı koz olarak kullanmadım, ama babasına çok kızgındım. 


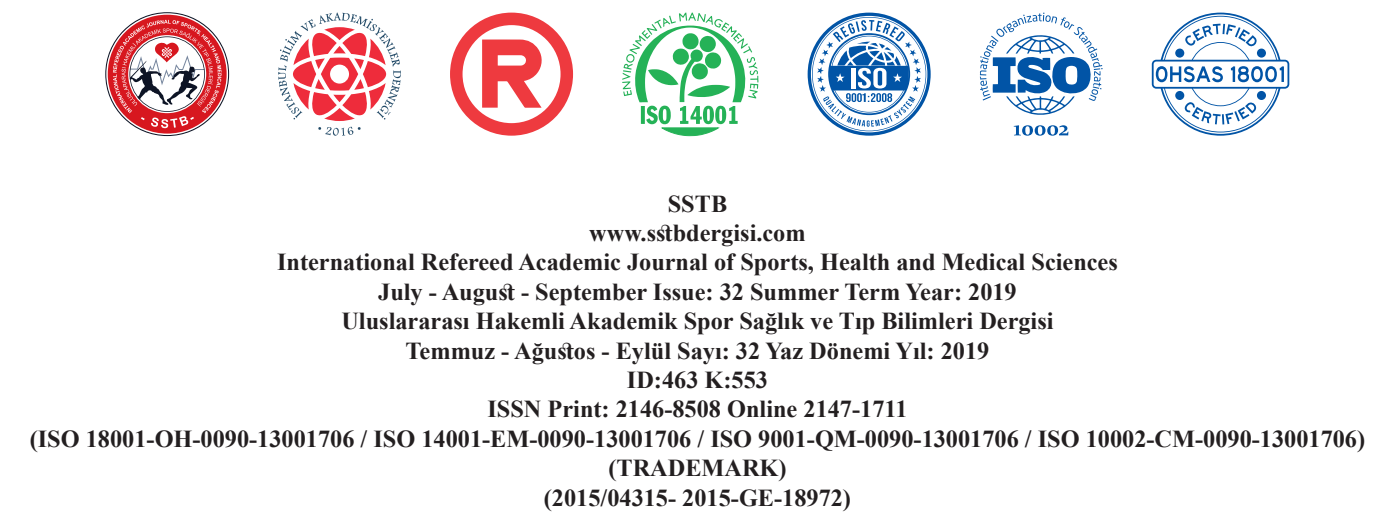

Aynı soru araştırmaya katılan ve çocuklarının velayeti kendisine verilmeyen babalara da sorulmuş (Eski eşinizin çocuğunuzu size karşı koz olarak kullandığını hissettiniz mi?) ve babaların büyük çoğunluğu bu durumdan rahatsız olduklarını belirtmişlerdir.

Erkek 12: Kesinlikle çocuklarımı kandırdı ve bana karşı kullandl. Bu yüzden aradan geçen bunca seneye rağmen 2 büyük kızla hala görüşmüyoruz. Önceleri çocuklarla görüşüyorduk. Daha sonraları çocukları benden uzaklaştırdı. Annelik duygularını kullanarak, kendisine acındirarak yaptı.

Erkek 30 (A): Tamamen koz olarak kullandl. Maalesef vicdansiz mahkemeler de bu kozları annelerden yana kullaniyor.

Erkek 10: Evet, eski eşim çoğunlukla çocukları göstermeyerek beni kendince cezalandır$d l$.

Erkek 20: Kesinlikle. Sanırım tekrar birleşmek için çocuğu yem gibi kullanıyordu. Benim çocuğuma ne kadar bă̆lı olduğumu bildiği için sanırım.

Ortak velayet ve boşanma uyum programları katılımcılara tanıtılmış; erkeklerin ortak velayet uygulamasına sıcak baktıkları, erkek ve kadınların hem ebeveynler için hem de çocuklar için hazırlanan boşanma uyum programlarına genel olarak olumlu olarak baktıkları görülmektedir.
Toplam 97 katılımcının "Boşanma (Aile) Arabuluculuğu" konusuna \% 72 oranında olumlu bakmalarının tespiti araştırmanın en önemli sonuçlarından birisi olarak tespit edilmiştir.

\section{TARTIŞMA}

Katılımcıların araştırmaya katıldığı andaki yaş ortalamasının 40.11 olduğu ve bu durumun araştırma için, birçok katılımcının boşanma sonrası yas sürecini tamamlamış olmaları nedeni ile araştırmanın sonuçlarını yorumlama açısından olumlu bir durum olduğu değerlendirilmiştir.

Katılımcıların Türkiye ortalamasına göre (2010 y1lı ilk evlenme yaşı erkeklerde 28.5, kadınlarda 24.5, araştırmaya katılan erkeklerde ortalama 27 ve kadınlarda 22,2) daha erken yaşlarda evlendikleri tespit edilmiştir. Bilen (2004: 17), kronolojik olgunluğa erişmeden gerçekleştirilen evliliklerde değer yargılarının ve beklentilerin ileriki yaşlarda değiştiği, erken yaşta evlenen bireylerin boşanmayı daha çabuk düşündüklerini, Martin ve Bumpass (1989: 26), erken yaşta yapılan evliliklerin yirmili yaşların ortalarında yap1lan evliliklere göre iki kat daha fazla boşanma ile sonuçlandığını, Glen ve Supancic (1984: 563) ise, erken yaşta evlenen bireylerin boşanmayı daha çabuk düşündüklerini belirtmektedir. Literatür bilgisi ile nitel bilgiler birlikte değerlendirildiğinde; katılımcıların 


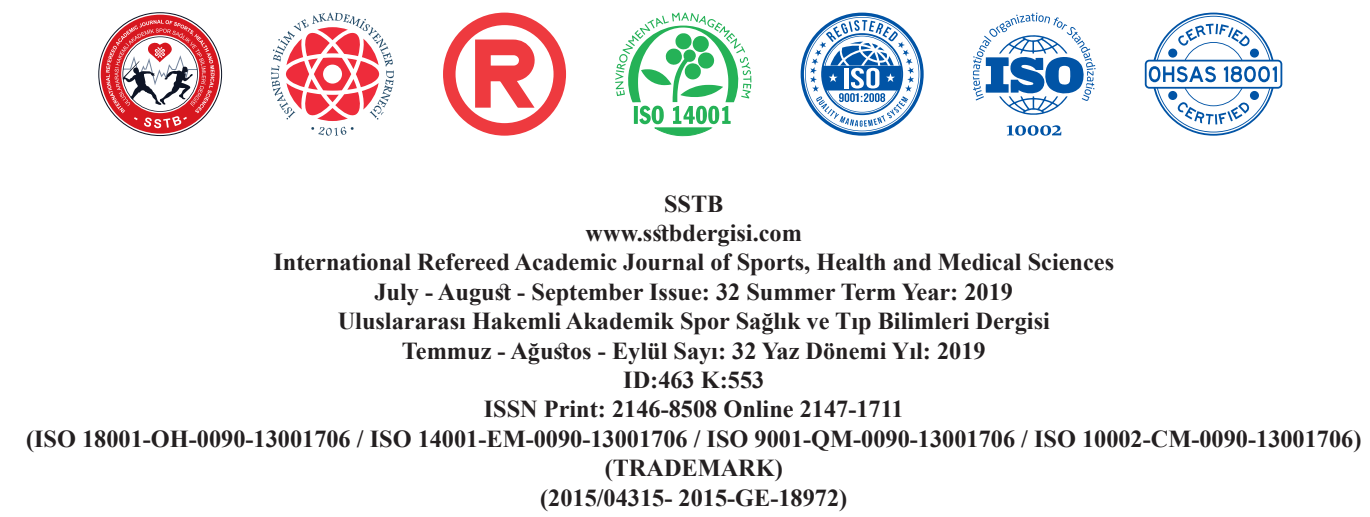

boşanmalarının gerçekleşmesinde genç yaşta evlenmelerin katkısı olduğu sonucuna varılmıştır.

Araştırmaya katılan katılımcıların mahkeme tarafından boşanma kararı verilene kadar evli kaldıkları sürenin ortalama 8.95 yıl olduğu görülmektedir. TÜIK (2011) verilerine göre 2010 y1lında 118.568 boşanma gerçekleşmiş ve bunun \% 40'1 evliliklerin ilk beş yllında gerçekleşmiştir. Araştırmada 97 katılımcıdan 41'i (\% 42,3), 53 kadından 21'i (\% 40), 44 erkeğin 20 'si $(\% 45,5)$ evliliklerinin ilk beş yılında ayrılmışlardır. Araştırma ile TÜiK (2011) sonuçları arasında benzerlik vardır. Araştırmada iki puan yüksek olmasının nedenlerinden birinin erken yapılan evlilikler sonucu olduğu değerlendirilmektedir.

Araştırmaya katılan 97 katılımcıdan 58'inin flört süresinin 0-6 ay arasında olduğu tespit edilmiştir. Çiftler arasındaki flört süresinin uzunluğu da birçok çalışmada ele alınmıştır. Uyar (1999), boşanan bireyleri etkileyen psikolojik, sosyal, ailesel ve bireysel etmenleri incelediği araştırmasında; evlilik öncesi tanışıklı süresinin bir yıldan az olmasının boşanma olasıllı̆ını artırdığını tespit etmiş̧ir. Ezici bir üstünlükle kısa süreli flört dönemi geçiren çiftlerin yüksek oranda boşanma riski yaşadıkları saptanmıştır (Hoedel, 2001: 145). Literatür bilgisi ile nitel bilgiler birlikte değerlendirildiğinde, bu durumun katılımcıların evliliklerinin erken evrelerinde boşanmaları- na tesir edebilecek bir etken olduğu düşünülmektedir.

Boşanma öncesi 14 kadın çalışmadığını belirtmiş, bunlardan 11 ' $\mathrm{i}$ boşanma sonrası işe başladığını, iş bulanlardan 10'u kolay iş bulamadığını belirtmiş̧tir. Eğitim durumu yüksek olanlar daha kolay iş bulurken, eğitim düzeyi düşük olanların iş bulmada sorun yaşadığı görülmektedir. Kadınların \% 94,3 gibi büyük bir çoğunlukla gelir getiren bir işte çalışmasının onların boşanmaya uyumlarını kolaylaştırabileceği değerlendirilmektedir.

Araştırmada özellikle 0-6 yaş arasında olan çocuk sayısının fazla olması dikkate değer bir sonuçtur. Evliklerin ortalama süresinin 8,9 yıl ve ilk beş yılda katılımcıların $\% 42,3$ 'ünün boşandığ1 düşünüldüğünde 61 çocuğun $0-6$ yaş arasında olması beklenen bir sonuçtur. Geri kalan 48 çocuğun büyük kısmının da okul çağı ve ergen çocuk olduğunu ve bu çocukların sağlıklı beden ve ruh durumu ile büyümesi için her iki ebeveyne de ihtiyacı olduğu açıktır. Ancak çocukları ile ayrı şehirlerde yaşayanlar ile çocuklarıyla aynı şehirde yaşamalarına rağmen çok kısıtlı kişisel görüş̧e hakkına sahip olan anne ve babaların olduğu, bu durumun yeni bir konu olarak literatüre giren "Ebeveyne Yabancılaşma Sendromu"nu tetiklediği ve derinleştirdiği, böylece "gözden rrak olan gönülden de rak olur" atasözünün gerçekleştiği ve velayet kendisinde olmayan bazı ebeveynler ile çocuklarının 


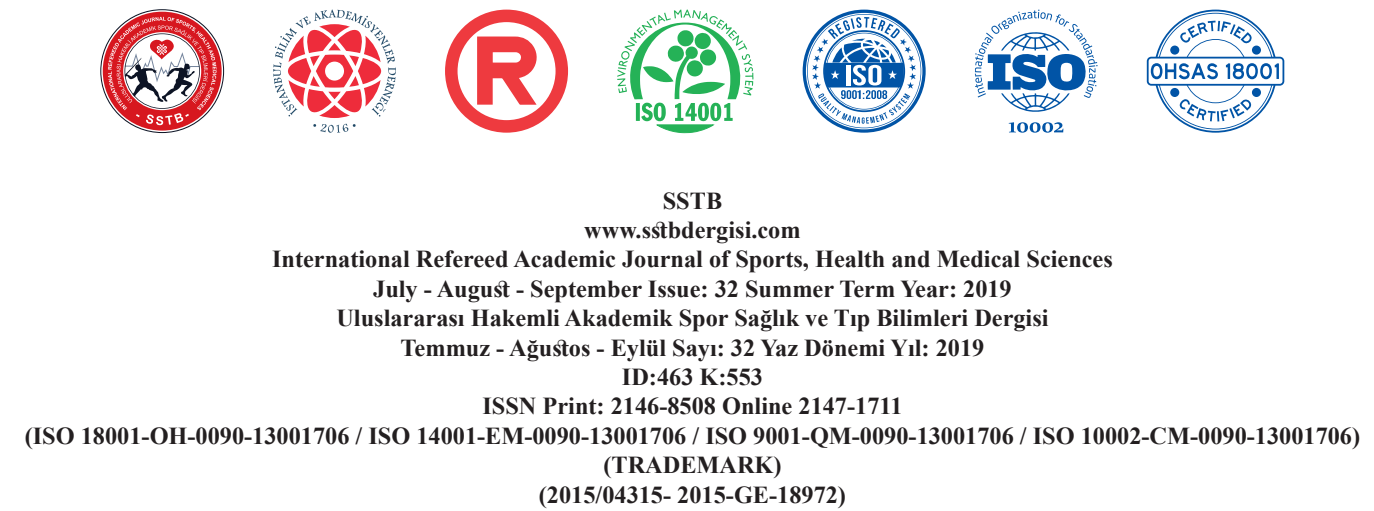

(2015/04315- 2015-GE-18972)

birbirini bıraktığı, arayıp sormadıkları bile görülmektedir. Acı bir gerçekte olsa, eşinden boşanıldığ gibi çocuktan da boşanılabilmektedir. Boşanma arabuluculuğu sistemi ile anlaşmalı olarak ayrılan çiftlerin çocukları ile olan görüşme zamanlarının daha fazla olabileceği ve sistemin bu anlamda önemli katkı da bulunabileceği değerlendirilmektedir.

Aile Mahkemesi kararlarının, taraflardan biri veya her ikisi tarafindan beğenilmeyerek bir üst mahkeme olan Yargitay 2. Hukuk Dairesine gönderildiği ve burada da iş yoğunluğunun (bu da mahkeme sonuçlarından memnuniyetsizliğin bir göstergesi olarak / y1lda 39854 (2012 y1lı) itiraz dosyasına bakılmaktadır) fazlalığından dolayı bir itiraz dosyasının karara bağlanması ortalama bir yıl sürmekte ve boşanma sürecini neredeyse iki katına çıkarmaktadır. Süreç bu kadarla kalmamakta ve Yargitay'dan dönen dosyalar aynı aile mahkemesi tarafından tekrar duruşma yapılarak yeni bir karar verilmektedir. Bu süreçte taraflar daha fazla yıpranmakta, birbirlerine kızgınlıkları ve husumet duyguları artmakta ve bu süreçte çocuklar da velayet kendisine verilmeyen ebeveyni daha az görmekte ve bu süreçten olumsuz olarak etkilenmektedirler. Bütün bu açıklamalardan sonra, aile (boşanma) arabuluculuğu sistemi ile, gerçek anlamda anlaşmalı boşanmaların yapılmasının sağlanarak mahkeme süreçlerinin kısalmasına veya hiç yaşanmasına gerek kalmadan ve taraflar ve çocuklarının bu süreçten zarar görmeden dostça ayrılınılmasına ve anne babalık görevlerinin sağlıklı koşullarda devamına imkan tanınabileceği değerlendirilmektedir.

Bulgular bölümünde açıkça görüldüğü gibi kadınlara evlilik boyunca uygulanan fiziksel şiddet boşanma sürecinde ve sonrasında giderek azalmış, ancak bazı evliliklerde boşanma gerçekleşmiş olmasına rağmen bitmemiştir. Evlilik boyunca uygulanan duygusal şiddet boşanma sürecinde ve sonrasında giderek azalmış, ancak birçok evlilikte boşanma gerçekleşmiş olmasına rağmen \% 50'nin altına inmemiştir. Bu duruma, nitel bulgular da dikkate alındığında; özellikle ortak çocukları nedeniyle iletişim kurmak zorunda olan eski eşlerin çocuk hakkında veya çocuk üzerinden evlilik çatışmalarını sürdürüyor olmasının etkili olduğu düşünülebilinir. Boşanma sonrası ekonomik şiddet boyutu mahkeme kararlar1nın uygulanıyor olması nedeniyle araştırmada sorgulanmamıştır. Bulgulardan da açıkça görüldüğü gibi evlilik boyunca uygulanan ekonomik şiddet boşanma sürecinde de devam etmiştir. $\mathrm{Bu}$ duruma, nitel bulgular da dikkate alındığında; duygusal olarak boşanmaya hazır olmayan bireylerin eşini boşanma kararından döndürmek veya mahkeme süreci/ boşanma sonrası süreç için kendisinden fazla nafaka, iştirak nafakası veya maddi/manevi tazminat talep edilmemesi için bir savunma mekanizması olarak veya evlilik boyunca 


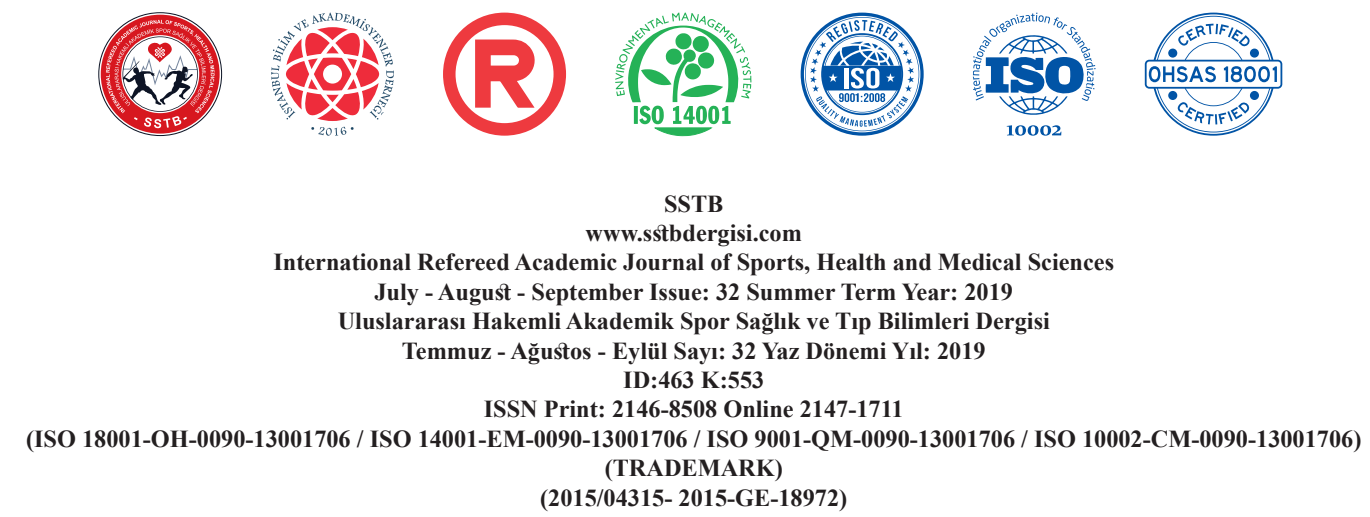

alışkanlık olarak sürdürülen ekonomik şiddet davranışlarının devam ettiriyor olmasının etkili olduğu düşünülebilinir. Aynı şekilde, evlilik boyunca uygulanan cinsel şiddet boşanma sürecinde ve sonrasında giderek azalmış, ancak bazı evliliklerde boşanma gerçekleşmiş olmasina rağmen bitmemiştir. Bu duruma, nitel bulgular da dikkate alındığında; duygusal olarak boşanmaya hazır olmayan bireylerin halen eski eşlerini karıları gibi görmeye devam etmesi ve cinsel isteklerini (çocuklarının annesi olması, belki de iletişime geçmenin daha kolay olması, eski eşin bunu kabullenebileceği beklentisi, yeniden eski eşiyle evlenme isteği veya beklentisi ve eski alışkanlıklarının da etkisiyle) eski eşleri ile gerçekleştirmesinin normal bir olgu gibi kabul ediyor olmasının etkili olduğu düşünülebilinir.

Aile (boşanma) arabuluculuğu sistemi ile; bu süreçte çiftlerin iletişim becerilerini ve sorun çözme yeteneklerini geliştirip, birbirlerini şimdi ve gelecekte daha iyi anlamalarına yardımcı olunurken, boşanmadan doğan haklarını kendi belirledikleri şekilde, göreceli olarak adil bir biçimde aldıklarını düşünmelerinden dolayı birbirlerine duydukları kızgınlık duygularının azalabileceği, öfke ile birbirlerine ve kök ailelerine zarar verme olasılıklarının azaltılabileceği ve medyada sıklıkla duyulan (özellikle boşanma sonrası ve boşanmış olmasına rağmen duygusal olarak boşanamamış erkeklerin eski eşlerine reva gördüğ̈̈) olumsuz olayların azaltılmasına destek olunabileceği düşünülmektedir.

Boşanma arabuluculuğu sistemi kullanılırken süreçte, sosyal hizmetin kullandığı ve araştırmada belirlenen yaklaşımlar ve özellikle güçlendirme yaklaşımı ile boşanma uyum programlarında bu desteğin bireylere verilebileceği ve boşanma sonrası dönemde boşanmış bireylerin ve çocuklarının yeni yaşam koşullarına daha kolay uyum sağlayabileceği ve yaşam kalitelerinin yükseltilmesine katk1 sağlanabileceği değerlendirilmektedir.

Gelişmiş ülkelerde arabulucu olabilecek kişi hakkında çok farklı yaklaşımlar olduğu görülmektedir. Sadece avukatların ya da hukuk kökenli insanların arabulucu olabileceği ülkelerin yanında, herkesin arabulucu olabildiği ülkeler, en azından üniversite eğitimine sahip olunması gereken ülkelerin olduğu görülmektedir. Örneğin Hollanda'da belli bir arabuluculuk eğitimi olan herkes arabulucu olabilmekteyken, Yunanistan'da sadece avukatlar arabulucu olabilmektedir (Schoneville, 2011). Avusturya'da arabuluculuk avukatlar arasında yürütülen ve diğer uzmanlar tarafından da yürütülebilecek bir uyuşmazlık çözüm tekniğidir (Roth, 2011). Almanya'da aile arabuluculuğu hem avukatlar hem de diğer meslek sahiplerince yürütülmektedir (Dendorfer, 2011). İspanya'da ise üniversite eğitimi olan herkes arabuluculuk yapabilmektedir (Tarrazon, 2011). Belçika'da uygulanan arabulucu- 


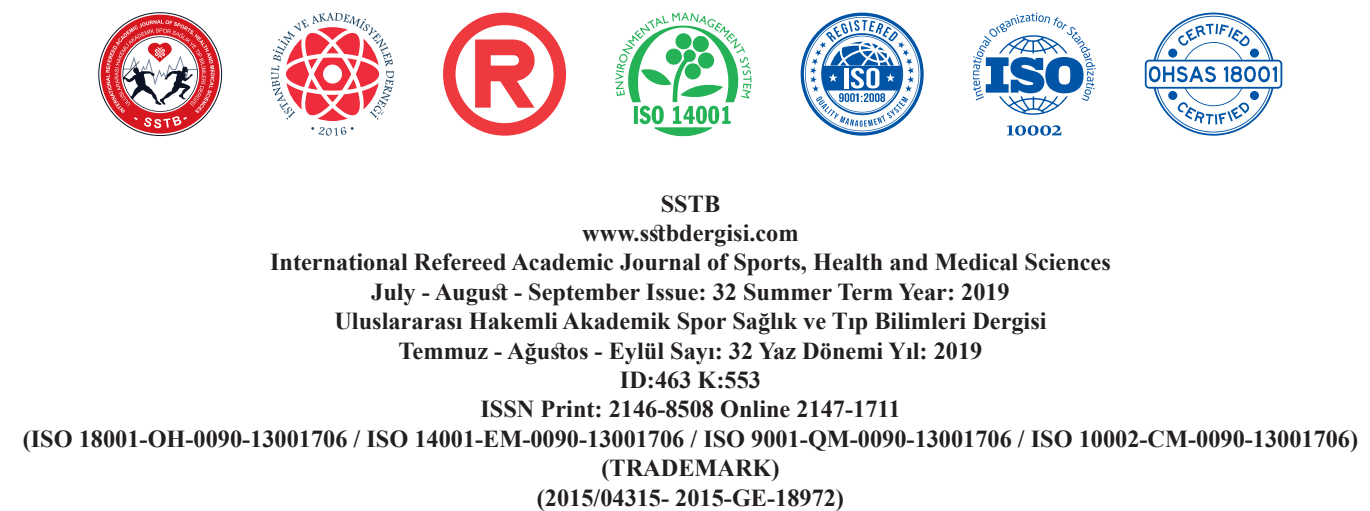

(2015/04315- 2015-GE-18972)

luk sistemini Demeyere (2011), aile arabuluculuğu alanında, arabulucunun uyuşmazlık konusunda uzman bir kişi mi olması gerektiği hususunda uzun süredir devam eden bir tartışma olduğunu ve bunun hakkında birçok fikir öne sürüldüğünü belirtmektedir.

Türkiye'de alternatif uyuşmazlık çözüm uygulamaları yapma hakk1 22.6.2012 tarih ve 28331 sayı numaralı Resmi Gazetede yayımlanan 6325 Kanun numaralı Hukuk Uyuşmazlıklarında Arabuluculuk Kanunu ile arabuluculuk eğitimi almış ve Adalet Bakanlığı kayıtlı arabulucu listesinde olmak koşuluyla hukuk eğitimi almış bireylere tanınmıştır. Aynı şekilde 2018 yılında Aile (boşanma) arabuluculuğu kanunu için yapılan çalışmalarda da; aile mahkemelerine intikal etmiş davaların hukuk eğitimi almış arabuluculara yönlendirilerek tarafların hazırladıkları anlaşmalı boşanma sözleşmesini hâkime onaylatmak üzere sunmaları ve hakim tarafindan onaylanarak boşanmaların gerçekleştirilmesi amaçlanmaktadır.

Ancak çocukların iyilik hali için konunun uzmanlarından destek alınması gerekmektedir. Adalet Bakanlığının tercüme ettirip bastırdığı "Aile Arabuluculuğu" kitabının yazarı Parkinson (2018), birçok ülkede aile arabulucularının nitelikli ve deneyimli sosyal hizmet uzmanları, terapistler veya psikologlardan oluşabileceğini belirtmektedir. Aynı şekilde ASPB Aile Danışmanlığı Yönetmeliği (2012,
Md.16/f), aile danışmanı görevlerinde "boşanma öncesinde ailelere psiko-sosyal süreç ve dinamikleri de dahil ederek arabuluculuk hizmetleri planlamak ve uygulamak" ifadesi de konunun uzmanlarının aile (boşanma) arabuluculuğu sürecine dahil edilmesi gerektiğini göstermektedir. Boşanma süreci ve sonrasında gerek çiftlerin gerekse çocuklarının iyilik hallerinin ve yaşam kalitelerinin artırılması ve aile ile toplumsal sorunların daha oluşmadan önleyici ve koruyucu tedbirlerle çözülmesi için aile (boşanma) arabuluculuğu Kanun ve Yönetmelik çalışmalarına sosyal hizmet akademisyenlerinin ve konunun uzmanlarının dahil edilmesi gerektiği düşünülmektedir.

\section{SONUÇ}

$\mathrm{Bu}$ araştırma ile boşanma deneyimini yaşamış kadın ve erkekler ile onların çocuklarının boşanma süreci, mahkeme süreci ve boşanma sonrası yaşadıkları yaşam deneyimleri incelenmiş̧tir. Aile (boşanma) arabuluculuğunun boşanma ile ilgili tüm süreçlerde boşanmanın olumsuz etkilerini azaltabileceği değerlendirilmektedir.

Araştırma bulgularına göre, boşanma tek bir faktörle açıklanamayacak kadar karmaşık bir yapı arz etmektedir. Boşanmanın gerçekleşmesine neden olan çok sayıda sosyal, kültürel, ekonomik ve psikolojik faktör olduğu bilinmekle birlikte bu faktörlerin değişik 


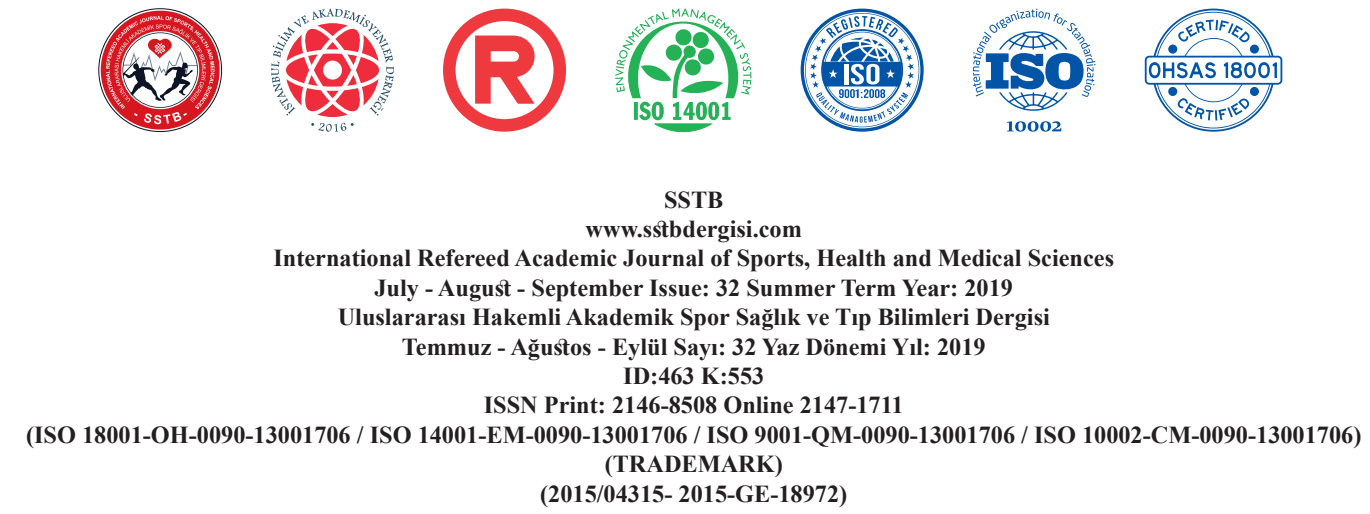

oranda katkısı evliliklerin kuruluş aşamasından itibaren yaşanan sorunları tetikleyerek boşanmada etkili olmaktadır.

Araştırma sonucunda; hem boşanma süreci hem de boşanma sonrası süreç birlikte değerlendirildiğinde, kadın ve erkeklerin boşanma sürecinin tamamını duygusal ve psikolojik, kızgınlık duygusu, sağlıklı savunma mekanizmalarının kullanılması, destek ihtiyacı anlamında sıkıntılı bir dönem olarak değerlendirdikleri ve kafalarının karışık olduğu, bazı bireylerin duygusal olarak boşanmaya hazır olmadan boşanmaya karar verdikleri sonucuna ulaşı1mıştır.

Araştırmaya katılan kadın ve erkeklerin boşanma nedenlerinde ortak noktalar olduğu gibi boşanmaya karar verirken temel düşüncenin evliliği biran önce bitirmek olduğu, hatta bunun için boşanmadan doğan haklarının birçoğuna mal olsa bile beklenilen anlamda olmayan anlaşmalı boşanma usullerini kullandıkları sonucuna ulaşılmıştır.

Anlaşmalı olarak boşanan 56 kadın ve erkeğin ancak yarısına yakınının (24 katılımcı) anlaşmalı boşanma memnuniyetinin yüksek olduğu değerlendirilmektedir. Aile (boşanma) arabuluculuğunun, evlilik doyumu kalmamış ve evliliğini mutlaka bitirmek isteyen bireyler arasında, gerçek anlamda anlaşmalı boşanmaların olmasına, boşanma sürecinde ve sonrasında hem kendileri hem de ço- cuklarının ruhsal ve fiziksel olarak örselenmeden ve boşanmadan doğan haklarını adil bir şekilde almalarına imkân sağlayabilecek bir sistem olabileceği ve aile mahkemesi hâkimlerinin onayladığı protokollerin de gerçek anlamda, her iki tarafın ve çocukların da kazandığı bir süreç sonrası hazırlanacağı değerlendirilmektedir. Bu anlamda, aile mahkemesi hâkimlerinin de dikkatlerini sayıca azalan mahkeme dosyasına ve çekişmeli boşanma dosyalarına yönlendirerek mesleki bilgi ve tecrübelerini tam olarak yansitabilecekleri ve iş doyumlarını artırabilecekleri değerlendirilmektedir.

Evlilik boyunca değişik oranlarda ve sıklıkta yaşanan kadına yönelik şiddet türlerinin boşanma sürecinde ve boşanma sonrası dönemde giderek azaldığı ancak tamamen ortadan kalkmadığı araştırmanın ulaştı̆̆ önemli sonuçlardan birisidir.

Aile içi şiddet boyutunda erkeklerin de \% 29,5 fiziksel şiddete, $\% 68,2$ duygusal şiddete ve \% 38,6 ekonomik şiddete evlilikleri boyunca değişik sıklıkta uğradıkları da araştırmada tespit edilen bulgulardan birisi olmuştur.

Yazıl1, sözlü ve görüntülü medya'da örneklerini gördüğümüz üzücü olayların kaynaklarından birinin de, boşanma sonrası önemli oranda azalmış olsa da devam eden şiddetin sonuçları olduğu görülmektedir. Aile (boşanma) arabuluculuğu ile, birçok konuda karş1- 


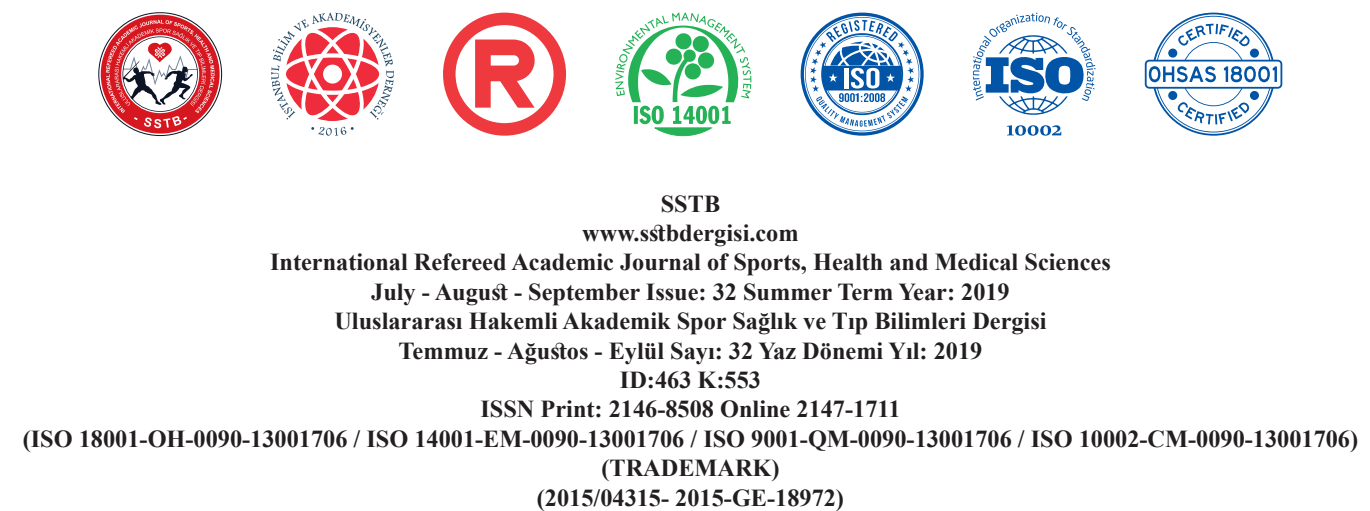

(2015/04315- 2015-GE-18972)

liklı olarak anlaşarak ve duygusal olarak da ayrılmaya hazır hale gelerek anlaşmalı olarak boşanan çiftlerin aralarında husumet duygularının azalması beklenen bir durumdur. Böylece, bu üzücü olayların giderek daha da azalabileceğine katkı açısından da aile (boşanma) arabuluculuğu sisteminin önemli olduğu değerlendirilmektedir.

Boşanmış bireylerin boşanma süreci, mahkeme süreci ve boşanma sonrası süreçte (özellikle çekişmeli boşanma yaşayanların) kendileri ve çocukları adına yaşadıkları olumsuz deneyimleri değerlendirerek "Aile-Boşanma Arabuluculuğu” konusuna \% 72 oranında olumlu bakmalarının tespiti araştırmadan çıkan en önemli sonuçtur.

Aile mahkemelerinin işleyişi ve hem hâkim hem de mahkeme uzmanlarının çalışması hakkında elde edilen nitel veriler ile sağlıklı bir değerlendirmenin bu araştırma sonunda yapılamayacağı düşünülmektedir.

Araştırmanın verilerinden faydalanılarak boşanma arabuluculuğu için yedi basamaklı bir model geliştirilmiştir. Bu basamaklar; tanışma, tanımlama, müzakere, uzlaşma, sözleşme, mahkeme süreci, boşanma süreci ve sonrası birey ve çocuklar için boşanmaya uyum programları süreci (destek programları) olarak belirlenmiştir.

Boşanmanın olumsuz etkilerinden aile üyelerinin korunması ve yaşam kalitelerinin artı- rılmasına yönelik; makro, mezzo, mikro seviyelerde ve araştırmacılara yönelik öneriler aşağıda yer almıştır:

Aile mahkemelerinde duruşmalar esnasında yaşanan gerginlikler, boşanmanın bir suç ve boşanan aile üyelerinin de bir suçlu olmadığı gerçeği göz önünde tutularak gerekli tedbirler ile giderilmelidir.

Araştırmanın mahkeme süreci memnuniyeti ile ilgili nicel ve nitel bulgular göz önüne alındığında; aile mahkemelerinin kendi yapısından kaynaklanan aksaklıkların da katkısı ve tarafların kendi istedikleri yönde çıkmayan mahkeme kararları sonucunda, gerek maddi gerekse manevi yönden kaybettikleri hissine kapılmaları ve boşanma sonrası husumetlerin oluşması ve muhtemel aile içi şiddet vakalarının artması beklenebilir. Bu olumsuz hususların azaltılması ve gerçek anlamda anlaşmalı boşanmaların gerçekleştirilebilmesi amacıyla; tarafların kontrolünde ve gönüllülük esasına göre yapılacak aile (boşanma) arabuluculuğu sisteminin ülkemizde kurulmasına, geliştirilmesine ve yaygınlaştırılmasına ihtiyaç vardır. Mahkeme içi ve mahkeme dışı süreçte boşanma arabuluculuğu yapacak hukukçular, aile mahkemesi uzmanları, resmi ve özel aile danışmanlık merkezi uzmanları bu konuda yeterli eğitime tabi tutulmalı ve etik ilkelere azami uymalıdırlar. 


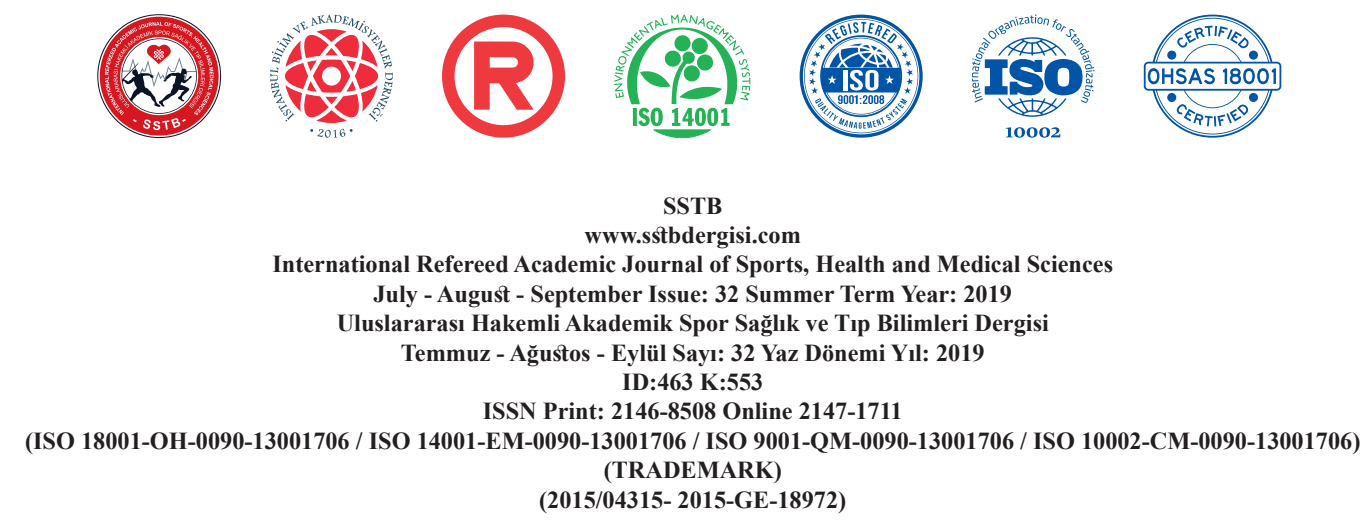

Araştırmaya katılan katılımcılardan velayet kendisine verilmeyen ebeveynlerin kendi ifadelerinden elde edilen nitel bulgular ve literatür bilgileri ışığında; Yargıtay 2. Hukuk Dairesinin, aynı şehirde yaşayan velayet kendisine verilmeyen ebeveyn ile en az 15 günde bir yatılı olarak çocuğu ile kişisel görüşme yapılması içtihat kararlarına rağmen, aile mahkemeleri hâkimleri kararlarında en iyi ihtimalle, direkt olarak her ayın birinci ve üçüncü hafta sonları çocuğun velayet kendisine verilmeyen ebeveyn ile kişisel görüş̧me hakkı olduğuna hükmetmektedirler. Ancak, en yakın örnek olan 2013 yılı takvimi esas alındığında; Mart, Haziran, Ağustos, Eylül, Kasım ve Aralık olmak üzere altı ayın beş hafta sonu çektiğini, dolayısıyla çocukların velayet kendisine verilmeyen ebeveyni 15 günde değil 21 günde bir gördüğü yadsınamayacak bir gerçektir. Eşine olan kızgınlığ geçmeyen velayet kendisinde olan ebeveynin uygulayabileceği "ebeveyne yabancılaşma sendromu" konusunda çocukların tehlikeye açık hale gelebileceği göz önüne alındığında; aynı şehirde olanlar için her hafta sonu cuma akşamından alıp cumartesi akşamına kadar veya $1-3$ ve 5 . hafta sonları velayet kendisinde olmayan ebeveyne kişisel görüş hakk1 verilmesinin; hem çocuğun ihtiyaç duyduğu sevgi, ilgi ve disiplin ihtiyacı ile cinsel ve sosyal kimliğinin oluşmasına katkı sağlayacak özdeşleşme ve rol model alabilmesi için gereken zamanı sağlayacağı, velayet kendi- sinde olmayan ebeveyn için çocuk sevgisini tadabileceği ve ebeveynlik görevlerini yerine getirmesi için zaman yaratacağ 1 ve her iki ebeveynin de ortak çocukları için anne ve babalık görevlerini düzenli olarak yapabilmeleri için firsat yaratabileceği ve çocukların ebeveyne yabancılaşma sendromu etkilerinden korunabileceği değerlendirilmektedir. Farklı şehirlerde yaşayan velayet kendisine verilmeyen ebeveynler içinde Türkiye'nin her yerine uçakla mesafenin bir saat olduğu değerlendirildiğinde; velayet kendisine verilmeyen ebeveynlerin istekleri doğrultusunda benzer tedbirler alınabilmelidir.

Avrupa Birliği ve ABD örneği incelenerek; ülkemiz koşullarına uygun, çocuğun fiziksel ve ruh sağlığını geliştirecek ve her iki ebeveynin de anne ve babalık görevlerini sağlıklı ve devamlı olarak yerine getirebilecekleri ortamı sağlayacak ortak velayet şartlarının gerek hukukçular gerekse akademisyenler tarafindan araştırılmasına ve bu yönde kanunlar yapılmasına ihtiyaç vardır.

Çocuğun üstün yararı için; kişisel görüşme hakk1 olan ebeveynin çocuğunu görememesi durumunda icra yolu ile çocuğunu alması prosedüründe yapılan tüm harcamaların çocuğu göstermeyen (velayet kendisinde olan) ebeveynden tahsil edilmesi, bu travmatik süreci ve tekrarlanmasını azaltabilecek bir önlem olabilir. 


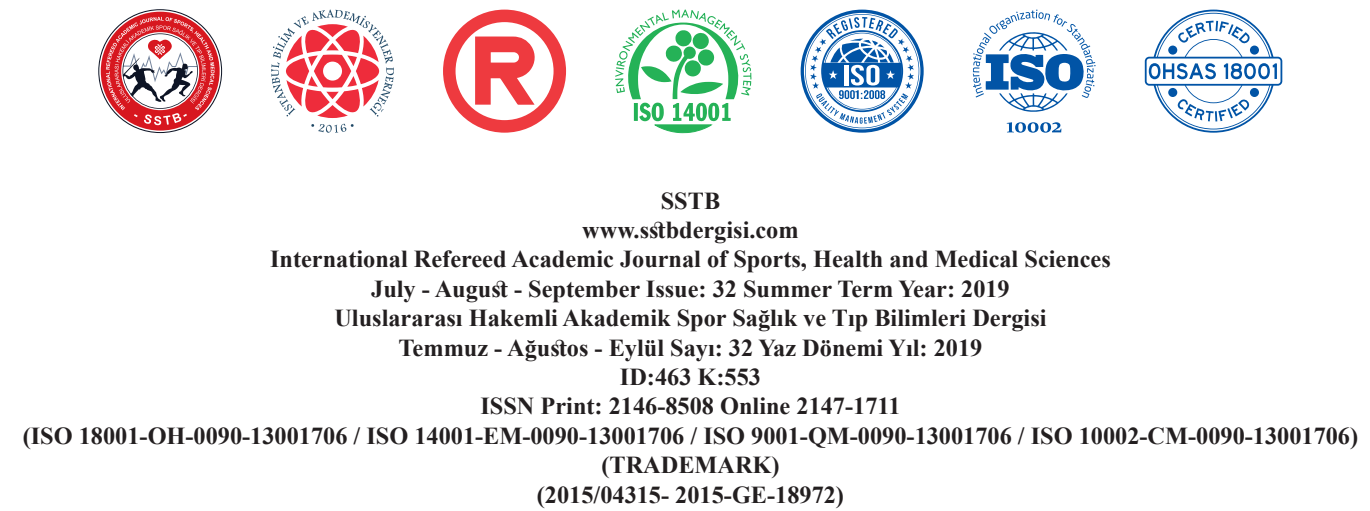

(2015/04315- 2015-GE-18972)

Araştırmaya katılan erkek ve kadınların evliliklerinin ilk yıllarında boşanma deneyimini yaşadıkları tespit edilmiştir. Gerek kendilerinin gerekse çocuklarının yeni yaşamlarına daha sağlıklı ve hızlı uyum sağlayabilmeleri ve yaşam kalitelerini yükseltmek için boşanma süreci ve sonrasında okul sosyal hizmeti kapsamında boşanma uyum programlarının açılmasına ihtiyaç olduğu değerlendirilmektedir.

Boşanma sonrası, özellikle küçük çocuğa sahip olan ve velayet kendisine verilen kadının ekonomik açıdan güçlendirilmesine ve sosyal hizmetin kullandığı yaklaşımlara, sosyal hizmet uzmanının mesleki yetenek ve rollerini başarıyla kullanmasına ihtiyaç vardır.

Araştırmada ayrılma kararını büyük oranda kadınların verdiği ve nitel bulgulardan elde edilen bilgiye göre erkeklerin duygusal olarak boşanmaya hazır olmadan boşanma deneyimini yaşadıkları ve eski eşlerine karşı, boşanma süreci ve sonrasında daha kırgın ve kızgın oldukları görülmektedir. Boşanma sonrası şiddetin önlenmesi anlamında bu hususun daha sonraki araştırmalarda incelenmesi önerilebilir.

Araştırmaya katılan katılımcıların kendi ifadelerinden elde edilen nitel bulgulardan da görüleceği üzere; katılımcıların bir kısmı sosyal dışlanma deneyimini yaşamışlardır. Çok boyutlu bir sosyal dişlanma süreci yaşayan birey ve ailelerine yönelik sosyal politikalar geliştirilmelidir.

Araştırmaya katılan katılımcıların aile danışmanlığ1 hakkında yeterli bilgileri olmadığ hususu araştırmanın nitel bulgularından tespit edilmiştir. Boşanma öncesi aile danışmanl1k hizmeti alınabilecek Aile ve Sosyal Politikalar Bakanlığına bağlı aile danışma merkezleri, özel aile danışma merkezleri ve Milli Eğitim Bakanlığına bağlı rehberlik araştırma merkezlerinin sayısı artırılmalı ve tanıtımlar1 yapılarak cazibe merkezi haline gelmeleri sağlanmalıdır.

Aile ve Sosyal Politikalar Bakanlığı ve Milli Eğitim Bakanlığı kontrolünde yapılan 450 saatlik aile danışmanlığı eğitimleri ve üniversitelerin açacağı aile danışmanlığ yüksek lisans eğitimlerinin müfredatlarına; araştırmanın incelediği ve araştırmaya katılan katılımcıların da olumlu baktıkları, aile (boşanma) arabuluculuğu, ebeveyne yabancılaşma sendromu, aile hukuku ve boşanma uyum programları konuları da eklenmelidir.

Araştırmada incelenen; boşanma arabuluculuğu, ebeveyne yabancilaşma sendromu ve ortak velayet konularında disiplinler arası araştırmalar yapılmalı, Türkiye şartlarında uygulanabilecek optimum uygulamalar ve sosyal politikalar üretilmesine katkı sağlanmalidir. 


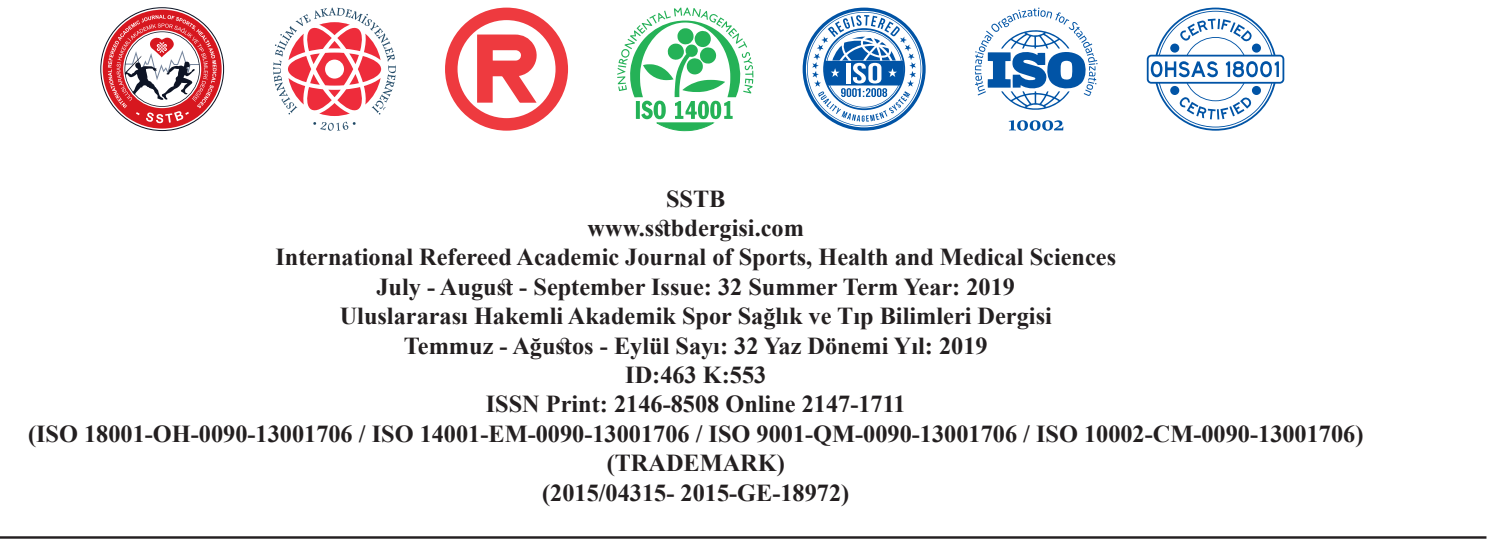

Boşanma süreci ve sonrasında gerek çiftlerin gerekse çocuklarının iyilik hallerinin ve yaşam kalitelerinin artırılması ve aile ile toplumsal sorunların daha oluşmadan önleyici ve koruyucu tedbirlerle çözülmesi için aile (boşanma) arabuluculuğu Kanun ve Yönetmelik çalışmalarına sosyal hizmet akademisyenlerinin ve konunun uzmanlarının dahil edilmesi gerektiği düşünülmektedir.

\section{KAYNAKÇA}

\section{AILE VE SOSYAL ARASTTIRMALAR GE-} NEL MÜD $\ddot{U} R \ddot{U} \breve{G} \ddot{U}$. (2009A). Boşanma nedenleri araştırması. Ankara

AILE VE SOSYAL ARAŞTIRMALAR GENEL MÜDÜRL $\ddot{U} \breve{G}$. (2009B). Türkiye'de aile mahkemeleri uygulaması ve uygulamanın değerlendirilmesi. Ankara

ASPB (2012). Gerçek kişiler ve özel hukuk tüzel kişileri ile kamu kurum ve kuruluşlarınca açılacak aile danışma merkezleri yönetmeliği. Resmi Gazete Sayısı: 28401, Tarihi: 04.09.2012

ARIFO $\breve{L} U$, B.Ç., (2006). Çocuklar için boşanmaya uyum programının çocukların boşanmaya uyum, kaygı ve depresyon düzeylerine etkisi. Yayınlanmamış yüksek lisans tezi. H.Ü. Sağlık Bilimleri Enstitüsü, Ankara. YÖK tez tarama tabanından incelenmiştir. (Tez No: 192620)
BAKTIR, S., (2003). Aile Mahkemeleri. Ankara: Yetkin Yayınları

BARKER, R.L., (1999). The Social Work Dictionary. NASW

BERKSUN, E.O., (2005). Boşanma. http:// www.psikiyatri.net/cat/index. (E.T. 15.10.2012)

BEYKONT, N. (2012). Ebeveyne yabancılaşma sendromu. www.bosanmisbabalarplatformu.com. (E.T. 15.11.2012)

BILLEN, M., (2004). Sağlıklı insan ilişkileri. Ankara: Anı Yayıncılık

BORNSTEIN, M.T., (1988). Children of divorce. Clinical Child Psychology, 17(3): 248-254

CILGA, I., (2001). Türkiye'de insan ve toplum sorunları karşısında sosyal hizmet. İnsani gelişme ve sosyal hizmet. Prof Dr. Nesrin Koşar"ea Armağan. K. Karataş ve Ç. Arıkan (Ed.). Ankara: Hacettepe Üniversitesi Sosyal Hizmetler Yüksekokulu Yayın No: 9

CILGA, I., (2002). Geleceğe yöneliş için mesleki güçlerin devingenliği. Sosyal hizmet eğitiminde yeniden yapılanma 1. Ankara: H.Ü. Sosyal Hizmetler Y.O. Yayını

CILGA, I., (2004). Bilim ve meslek olarak Türkiye'de sosyal hizmet. Ankara: Ha- 
International Refereed Academic Journal of Sports, Health and Medical Sciences

July - August - September Issue: 32 Summer Term Year: 2019

Uluslararası Hakemli Akademik Spor Sağlık ve Tıp Bilimleri Dergisi

Temmuz - Ağustos - Eylül Sayı: 32 Yaz Dönemi Yıl: 2019 ID:463 K:553

ISSN Print: 2146-8508 Online 2147-1711

(ISO 18001-OH-0090-13001706 / ISO 14001-EM-0090-13001706 / ISO 9001-QM-0090-13001706 / ISO 10002-CM-0090-13001706) (TRADEMARK)

cettepe Üniversitesi Sosyal Hizmetler Yüksekokulu Yayını, Ümit Ofset Matbaac1lik

CRESWELL, J.W., (2009). Research design: Qualitative, quantitative and mixed methods approaches. Thousand Oaks, California: Sage Publications.

DENDORFER, R., (2011). Dünyada arabuluculuk uygulamaları konferans kitapç1ğ1 içinde (2012). Türkiye Barolar Birliği Yayınları: 216

DEMEYERE, L., (2011). Dünyada arabuluculuk uygulamaları konferans kitapçığı içinde (2012). Türkiye Barolar Birliği Yayınları: 216

DUYAN, V., (2008). Sosyal hizmeti tanımak ve anlamak. Ankara: Sosyal Hizmet Uzmanları Derneği Genel Merkezi Yayınları

ERKAN, G., (1986). Boşanmanın çocukların benlik tasarımına etkisi. Yayınlanmamış doktora tezi. H.Ü. Sosyal Bilimler Enstitüsü Psikolojik Danışmanlık ve Rehberlik ABD. Ankara

FISHER, B., (1998). Sona eren ilişkinin ardından yeniden toparlanmak. (S. Eren, Çev.). İstanbul: HYB Yayıncılık. (Orijinal basım tarihi 1981 ve 1992)
GARDNER, R.A., (1998). The parental alienation syndrome. Cresskill, NJ: Creative Therapeutics Inc

GEASLER, M.J., BLAISURE, K.R., (1998). A review of divorce education program materials. Family Relations, 47(2): 167175

GLENN, N.D., SUPANCIC, M., (1984). The social and demographic correlates of divorce and separation in The United States: An update and reconsideration. Journal of Marriage and the Family, (46): 563-576

HOEDEL, J.M., (2001). Evaluating the short term effectiveness of the prepare 2000 premarital enrichment program: An exploratory study of change in premarital couples. Doktora tezi. Michigan Üniversitesi, USA. ProQuest Digital Dissertations veri tabanından incelenmiştir. (UMI Number: 3036681, E.T. 11.01.2012)

HORTAÇSU, N.(1991). İnsan ilişkileri. Ankara: İmge Kitabevi Yayınları.

HÜNLER, S.O., GENÇÖZ, T., (2003). Воyun eğici davranışlar ve evlilik doyumu ilişkisi: Algılanan evlilik problemleri çözümünün rolü. Türk Psikoloji Dergisi, 18(51): 99-108 
International Refereed Academic Journal of Sports, Health and Medical Sciences July - August - September Issue: 32 Summer Term Year: 2019

Uluslararası Hakemli Akademik Spor Sağlık ve Tıp Bilimleri Dergisi Temmuz - Ağustos - Eylül Sayı: 32 Yaz Dönemi Yıl: 2019 ID:463 K:553

ISSN Print: 2146-8508 Online 2147-1711

(ISO 18001-OH-0090-13001706 / ISO 14001-EM-0090-13001706 / ISO 9001-QM-0090-13001706 / ISO 10002-CM-0090-13001706) (TRADEMARK)

KOÇYILDIRIM, G., (2010). Sosyal hizmet bakış açısıyla çocuk teslimine ve çocukla kişisel ilişki kurulmasına dair ilamların icrası uygulamaları. Yayınlanmamış yüksek lisans tezi.Hacettepe Üniversitesi Sosyal Bilimler Enstitüsü Sosyal Hizmet ABD. Ankara. YÖK tez tarama tabanından incelenmiştir (Tez No: 265214, E.T. 12.01.2012)

MATHELIN, C., (2009). Freud'a ne yaptık da çocuklarımız böyle oldu? ( E. Gültekin, Çev.). İstanbul: Kitap Yayınevi. (Orijinal basım tarihi 2000)

ÖZUĞURLU, K., (1990). Evlilik raporu. İstanbul: Altın Kitaplar Yayınevi

PARKINSON, L., (2018). Aile arabuluculuğu. (Çeviri) Ankara: Adalet Bakanlığ 1 Basımevi. (Orijinal basım tarihi 2017)

PUNCH, F.K., (2005). Sosyal araştırmalara giriş: Nitel ve nicel yaklaşımlar. (D. Bayrak, H. B. Arslan, Z. Akyüz, Çev.). Ankara: Siyasal Kitabevi. (Orijinal basim tarihi 2. Bask1 2005)

ROTH, M., (2011). Dünyada arabuluculuk uygulamaları konferans kitapçığı içinde (2012). Türkiye Barolar Birliği Yayınları: 216

SCHONEVILLE, M., (2011). Dünyada arabuluculuk uygulamaları konferans kitap- çı̆̆1 içinde (2012). Türkiye Barolar Birliği Yayınları: 216

SHAW, L.A., (2010). Divorce mediation outcome research: A meta-analysis. Conflict Resolution Quarterly, 27(4): 447-467

SOYGÜT, M., (2006). Türk ceza ve ceza usul hukukunda uzlaşma kurumu. Yayınlanmamış yüksek lisans tezi. Galatasaray Üniversitesi Sosyal Bilimler Enstitüsü Kamu Hukuku Anabilim Dalı, İstanbul. YÖK tez tarama tabanından incelenmiştir (Tez No: 217765, E.T. 15.01.2012)

STAHMANN, R.F., HIEBERT, W.J., (1997). Premarital counseling: The professional's handbook. New York: Lexington Books

ŞEN, B., (2009). Evlenmek üzere başvuruda bulunan bir grup nişanlı çiftin evlilik ve 'evlilik öncesi çift eğitimi'ne ilişkin bilgi, görüş ve değerlendirmeleri. Yayınlanmamış yüksek lisans tezi. H.Ü. Sosyal Bilimler Enstitüsü Sosyal Hizmet ABD. Ankara. (YÖK Tez No: 258407)

ŞENEL, H.G., (2004). Eş seçim kararı. Evlilik okulu. H. Yavuzer (Ed.). İstanbul:

Remzi Kitabevi

TANRIVER, S., (2006). Hukuk uyuşmazlıkları bağlamında alternatif uyuşmazlık çözüm yolları ve özellikle arabuluculuk. Türkiye Barolar Birliği Dergisi, 64, 151- 179 
International Refereed Academic Journal of Sports, Health and Medical Sciences

July - August - September Issue: 32 Summer Term Year: 2019

Uluslararası Hakemli Akademik Spor Sağlık ve Tıp Bilimleri Dergisi

Temmuz - Ağustos - Eylül Sayı: 32 Yaz Dönemi Yıl: 2019 ID:463 K:553

ISSN Print: 2146-8508 Online 2147-1711

(ISO 18001-OH-0090-13001706 / ISO 14001-EM-0090-13001706 / ISO 9001-QM-0090-13001706 / ISO 10002-CM-0090-13001706) (TRADEMARK)

TARRAZON, M., (2011). Dünyada arabuluculuk uygulamaları konferans kitapçı̆̆1 içinde (2012). Türkiye Barolar Birliği Yayınları: 216

TASHAKKORI, A., TEDDLIE, C., (1998). Mixed methodology: Combining qualitative and quantitative approaches, applied social research methods series, London: Sage Publications

UYAR, S., (1999). Boşanmış bireylerin evlilik süreci ve bugüne ilişkin psikolojik sorunları üzerine bir araştırma. Yayınlanmamış uzmanlık tezi. GATA. Ankara. YÖK tez tarama tabanından incelenmiştir (Tez No: 86876, E.T.17.01.2012)

WALTON, L., OLIVER, C., GRIFFIN, C., (1999). Divorce mediation: The impact of mediation on the psychological wellbeing of children and parents. Journal of Community and Applied Social Psychology, 9(1): 35-46

YILDIRIM, I., (1993). Evli bireylerin uyum düzeni. 3P Psikiyatri, Psikoloji,Psikofarmakoloji Dergisi, 1(3): 249-257

YILDIRIM, A., ŞIMSŞEK, H., (2005). Sosyal bilimlerde nitel araştırma yöntemleri. Ankara: Seçkin Yayınevi

ZASTROW, C., (1995). The practice of social work. California: Brooks/Cole Publishing

YAZAR NOTU: Bu makale "Bosanma süreci ve arabuluculuğu” isimli doktora tezinden uyarlanmustor. 


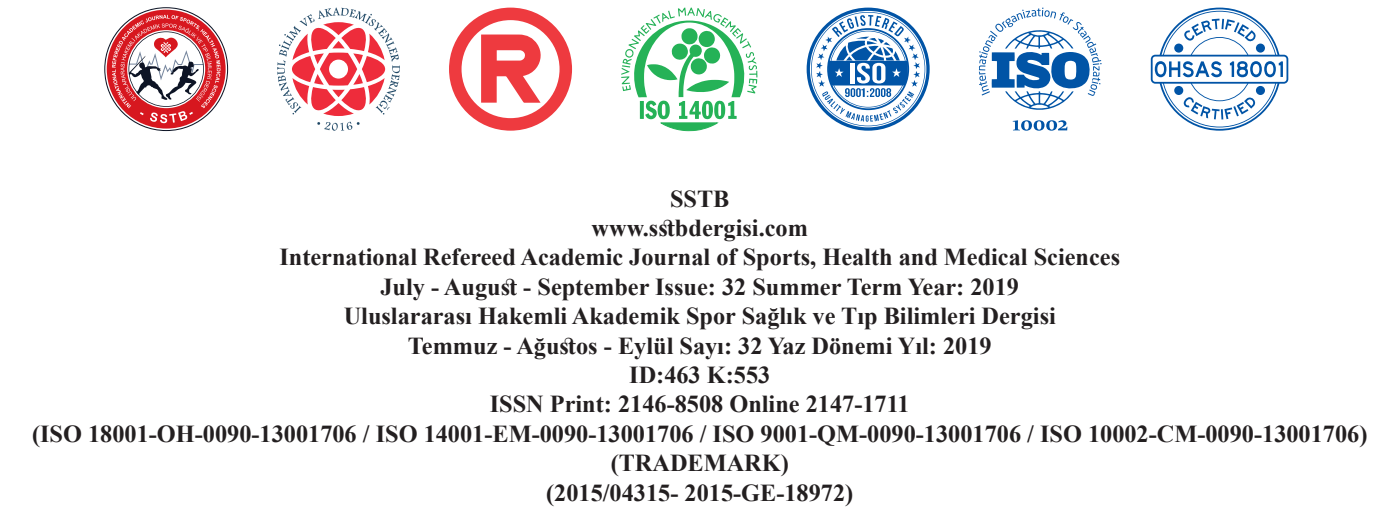

\section{EXTENDED ABSTRACT}

Aim: The economic, social and cultural changes that have emerged in our society in the last hundred years have brought about important structural and functional changes in family and marriage institutions. Divorces, broken families, motherless and/or fatherless children have become the cases of everyday life. Mediation can be used in many areas, but it can also be used successfully in the process of divorce involving multidimensional problems. Divorce mediation is defined as a series of process steps used by social workers, lawyers and other professionals to help solve problems among the couples in the divorce period, apart from the family courtrooms where the two sides are experiencing processes where their negative feelings are reinforced. The main problem of this study was the divorce phenomenon, which was rapidly increasing since the $2000 \mathrm{~s}$, the negative experiences of the family members' divorce process, the court process and the post-divorce process, and the lack of scientific knowledge to make this process more positive. In this study, the divorce process of men and women who have gone through a divorce experience and their children, the court process and the life experiences that they have experienced after getting divorced is examined. The issue whether divorce mediation will decreases the negative effects of divorce on all the processes or not and how the research participants viewed the idea of family (divorce) mediation has been questioned. Method: A mixed model study has been used at the research. The structured and semi structured interview form for the quantitative and qualitative data collection; has been prepared in one single form and different for women and men. In-depth interviews with survey attendees were conducted face-to-face. Living in Ankara Metropolitan Municipality borders, a total of 97 participants, 53 of which were ladies and 44 of which were male participants who had a divorce experience, participated at the study. Data were collected in two stages. In the first stage, data collection tools were applied at the same time. At the first stage, the interview form, where qualitative and quantitative information was collected, was given to 97 participants and after the completion of these forms, efforts were made to enrich qualitative information with 56 participants who agreed to make in-depth face-to-face interviews with body language, mood, and instant statements. The interviews were asked to use a voice recorder and only 8 participants were allowed to do so. The interview form is structured (for quantitative information) and semi-structured interview form (for qualitative information) as a single form and prepared for men and women to be different. During the in-person face-to-face interview, the interview was conducted in a way that was asked in a way that was non-directing, ineffective, encouraged, encouraging and 


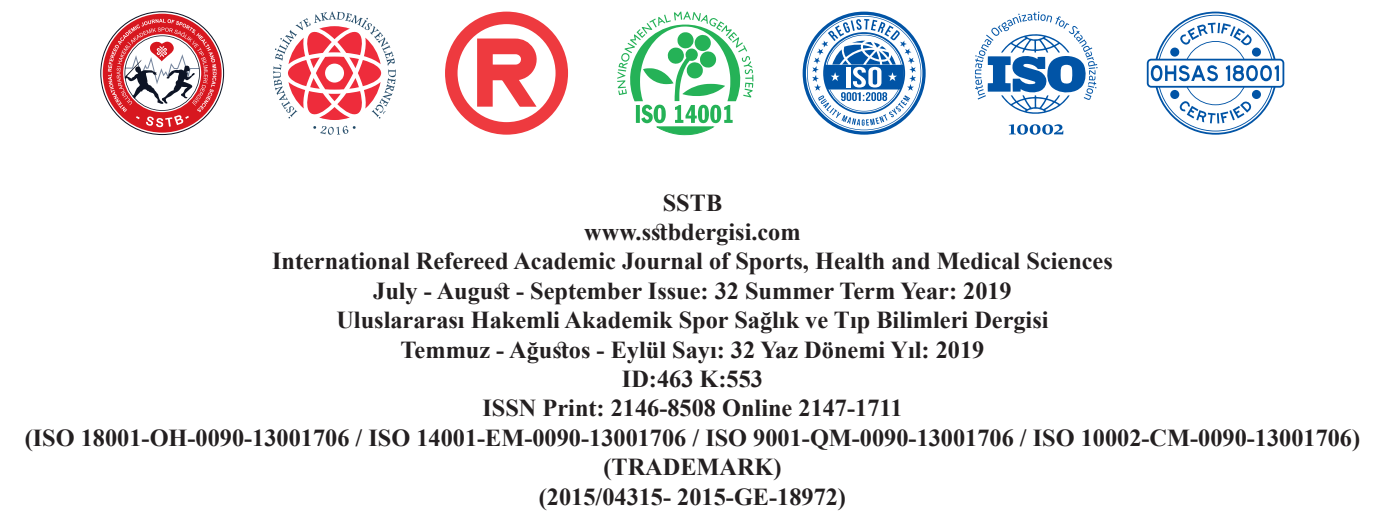

(2015/04315- 2015-GE-18972)

feedback. Quantitative information obtained from the interview form used in the research were analyzed with the help of SPSS 11.5 package program. In this study, the qualitative data obtained from interviews with men and women who had a divorce experience were interpreted by descriptive analysis method. In this study, qualitative research data were evaluated in four themes (18 categories and 84 subcategories). Findings: It has been identified that, gettting married of the participants at a young age have contributed to their divorce, that the average time period they were married is 8.95 years, that nearly half of the participants' divorce took place in the first five years of their marriage, that less than one year duration of acquaintanceship between the couples before marriage increases the possibility of divorce, that those who start to work after divorce with higher education are likely to find jobs more easily, that those with low levels of education had trouble finding a job, that those who had a job that generates an income could adapt more easily to divorce, that the divorce of participants has affected 61 children between the ages of 0-6 (56\%) and 48 children aged 7-18 years (44\%), that these children would need both parents in order to grow up with a healthy body and mind, that the court process of the divorces takes in average one year, that it would take in average one year to finalise the decision of an appeal file at a higher court. One of the important conclusions reached by the study is, that violence experienced in different proportions and types during marriage gradually decreases during the divorce process and during the period after the divorce, but it does not completely disappear. When both the divorce process and the course after the divorce are evaluated together, it has been seen that the the vast majority of men and women have evaluated the entire process of divorce as a troubled time with regards to emotional and psychological feelings, with regards to the sense of anger, the need for support, preparation period for divorce and the adaptation to the requirements of divorce. It has been seen that both women and men were thinking that there are common grounds to the divorce, that the basic idea when deciding to divorce is to finish the marriage as soon as possible and that both women and men were thinking that they could not get their rights arising from the divorce. Only nearly half of the 56 men and women (24 participants) who have divorced by consensual divorce (divorce by separation agreement and property settlement) considered that the satisfaction due to the consensual divorce is high. Results and conclusion: Family (divorce) mediation system; In this process, it is evaluated that couples will improve their communication skills and problem-solving skills and help them to understand each other better now and in the future. It is thought that their feelings of anger may be reduced because they think that they have received their right of divorce in a relatively fair manner as they have determined. In addition, it is thought that anger can reduce the likelihood 
International Refereed Academic Journal of Sports, Health and Medical Sciences

July - August - September Issue: 32 Summer Term Year: 2019

Uluslararası Hakemli Akademik Spor Sağlık ve Tıp Bilimleri Dergisi

Temmuz - Ağustos - Eylül Sayı: 32 Yaz Dönemi Yıl: 2019 ID:463 K:553

ISSN Print: 2146-8508 Online 2147-1711

(ISO 18001-OH-0090-13001706 / ISO 14001-EM-0090-13001706 / ISO 9001-QM-0090-13001706 / ISO 10002-CM-0090-13001706) (TRADEMARK)

(2015/04315- 2015-GE-18972)

of harm to each other and root families, and can help to reduce the negative events that are frequently heard in the media (especially after divorce and divorce, which men who have not been divorced by their former spouses). It is thought that this support can be given to individuals in divorce adaptation programs by using the divorce mediation system and the social empowerment approach. It is evaluated that divorce individuals and their children can adapt more easily to the new life conditions and contribute to the improvement of their quality of life. The most important result of the study is the identification that $72 \%$ of the divorced individuals were looking at the "family (divorce) mediation" in a positive way. The facts of Parental Alienation and joint custody have been examined in a survey together for the first time. It is proposed that the social service academics and experts of the subject should be included to work during the preparation of the law on family (divorce) mediation. 